\title{
APPLICATION OF GREEN COMPOST AS AMENDMENT IN AN AGRICULTURAL SOIL: EFFECT ON THE BEHAVIOUR OF TRIASULFURON AND PROSULFOCARB UNDER FIELD CONDITIONS
}

J.M. Marín-Benito, V. Barba, J.M. Ordax, M.S. Andrades, M.J. Sánchez-Martín, M.S. Rodríguez-Cruz*

Instituto de Recursos Naturales y Agrobiología de Salamanca (IRNASA-CSIC), C/ Cordel de Merinas 40-52, 37008 Salamanca, España.

*Corresponding author.

E-mail address: msonia.rodriguez@irnasa.csic.es (María Sonia Rodríguez-Cruz)

Tel.: +34 923219606. Fax: +34 923219609 


\section{Abstract}

Herbicides are essential in agricultural systems for maintaining crop yields, as weeds compromise grain production. Furthermore, the application of organic amendments to soil is an increasingly frequent agricultural practice for avoiding irreversible soil degradation. However, this practice could modify the behaviour of the herbicides applied, with implications for their absorption by weeds. This study evaluated the dissipation, persistence and mobility of the herbicides triasulfuron and prosulfocarb in a sandy clay loam soil unamended and amended with green compost (GC) in a field experiment using single or combined commercial formulations of both herbicides. The study was carried out in experimental plots (eight treatments $\times$ three replicates) corresponding to unamended soil and soil amended with GC, untreated and treated with the herbicide formulations $\operatorname{Logran}^{\circledR}$, Auros $^{\circledR}$ and Auros Plus ${ }^{\circledR}$ over 100 days.

The half-life $\left(\mathrm{DT}_{50}\right)$ of triasulfuron applied individually was 19.4 days, and increased in the GC-amended soil (46.7 days) due to its higher adsorption by this soil, although non-significant differences between $\mathrm{DT}_{50}$ values were found when it was applied in combination with prosulfocarb. Prosulfocarb dissipated faster than triasulfuron under all the conditions assayed, but non-significant differences were observed for the different treatments. The analysis of the herbicides at different soil depths $(0-50 \mathrm{~cm})$ after their application confirmed the leaching of both herbicides to deeper soil layers under all conditions, although larger amounts of residues were found in the $0-10$ and $10-20 \mathrm{~cm}$ layers. The application of GC to the soil increased the persistence of both herbicides, and prevented the rapid leaching of triasulfuron in the soil, but the leaching of prosulfocarb was not inhibited. The influence of single or combined formulations was observed for triasulfuron, but not for prosulfocarb. The 
results obtained highlight the interest of obtaining field data to design rational joint applications of GC and herbicides to prevent the possible decrease in their effectiveness for weeds or the risk of water contamination.

Keywords: dissipation, mobility, organic amendment, soil, commercial herbicide formulations

\section{Introduction}

Herbicides are essential in agriculture systems worldwide for protecting crops against weeds. Besides, the application of organic amendments to soil is an increasingly frequent agricultural practice in Spain for avoiding irreversible soil degradation. These materials increase the amount of organic matter (OM) in the soil, which plays a key role in the development and functioning of terrestrial ecosystems (García Izquierdo and Lobo Bedmar, 2008) and have attracted considerable interest in recent years (Scotti et al., 2015). In Spain, rising potentially exploitable organic wastes includes biodegradable wastes generated by pruning in parks and gardens. These residues referred to as green compost (GC) become materials with $\mathrm{OM}>15 \%$, and they could be used as organic amendments.

However, this practice could lead to changes in the behaviour of herbicides applied in amended soils (Barriuso et al., 1997). The herbicides could be adsorbed by amended soils, and this could have consequences for their degradation, persistence or mobility (Marín-Benito et al., 2012, 2013; Rodríguez-Liébana et al., 2014; Keren et al., 2017). These processes could decrease pollution by herbicides, but they could also affect the final concentration bioavailable for their absorption by the targeted weeds (Barriuso et al., 1997). These effects are generally studied in the laboratory, with fewer studies being carried out under real field conditions (Herrero-Hernández et al., 2011, 
Triasulfuron and prosulfocarb are two herbicides used in pre- and postemergence against weeds in winter cereals (wheat and barley) and other crops (potato). Triasulfuron is a sulfonylurea with high water solubility and a low hydrophobic nature (PPDB, 2017). This compound is a weak acid (pKa 4.8) found, predominantly as an anion at high $\mathrm{pH}$ and thus being more available for plants, while in acid soils it is less available since it is more adsorbed by soil (EC, 2000). In high pH soils, therefore, the rapid leaching of the herbicide and a deeper displacement of triasulfuron slowly degrading in the profile are to be expected because microbial activity usually decreases with depth. The influence of biotic (microbial activity) and abiotic $(\mathrm{pH})$ factors on its persistence have been reported (Singh and Kulshrestha, 2006), as well as the influence of adsorption by soil on triasulfuron's biodegradation and bioavailability (Said-Pullicino et al., 2004).

The dissipation of triasulfuron herbicide has been studied in the laboratory and in the field (EC, 2000; Gennari et al., 2008), while only some laboratory studies have evaluated the effect of the herbicide's application dosage (Sofo et al., 2012, Pose-Juan et al., 2017) or the influence of $\mathrm{OM}$ on its adsorption and dissipation in amended soils (Said-Pullicino et al., 2004; Pinna et al., 2009; Pose-Juan et al., 2017). Evaluating the changes in mobility and the persistence of this herbicide by soil amendment is therefore of interest, as it could impact negatively on the performance of future crops (Menne and Berger, 2001; Sarmah et al., 1998, 2000). In fact, this herbicide has been reported to persist in soil at phytotoxic concentrations for more than a year after application, especially at low temperatures and high $\mathrm{pH}$, causing damage to sensitive crops in subsequent rotations (James et al., 1999). 
Prosulfocarb is a thiocarbamate non-ionic and hydrophobic compound (PPDB, 2017). Mean values of the time required for the concentration to decline to half of the initial value $\left(\mathrm{DT}_{50}\right)$ between 15.2 and 10.1 days were reported for different soil types under laboratory and field conditions, respectively (EFSA, 2007). The dissipation of prosulfocarb is due mainly to a microbial process, and Gennari et al. (2002) have reported that the degradation rate was inversely correlated with organic carbon (OC) content. Accordingly, it records high adsorption and persistence associated with all soil OM fractions (Braun et al., 2017) which lead to a decrease in leaching and plant bioavailability, and therefore in herbicide performance (Négre et al., 2006).

Weed control in cereals with these herbicides is widely recommended, using them as the single formulations $\operatorname{Logran}{ }^{\circledR}$ and Auros ${ }^{\circledR}$, respectively, or as a combined formulation of both herbicides, Auros Plus ${ }^{\circledR}$ (De Liñán Vicente and De Liñán Carral, 2008). The application of Auros $^{\circledR}$ is recommended as a combined formulation with other herbicides when a varied infestation occurs or for managing weeds' herbicide resistance (Busi and Powles, 2016). The studies in the literature generally evaluate the behaviour of individual molecules in unamended soils, but to our knowledge no one has addressed the dissipation of these herbicides applied in combination or in the presence of organic amendments. It has been reported that microbial activities could be affected by the presence of an herbicide in the soil, and this could affect the degradation, persistence and leaching of another herbicide applied at the same time (Fogg et al., 2003; Swarcewicz et al., 2013; dos Reis et al., 2017).

Accordingly, this study was carried out to evaluate the dissipation, persistence and mobility of the herbicides triasulfuron and prosulfocarb in a sandy clay loam soil. A field experiment was set up, and the effects of single or combined commercial 
formulations of these herbicides, until now not studied, on the dissipation of individual compounds was evaluated in an unamended soil and in a soil amended with GC.

\section{Materials and methods}

\subsection{Herbicides}

This study used the commercial formulations of triasulfuron (Logran ${ }^{\circledR} 20 \% \mathrm{p} / \mathrm{p}$ ), prosulfocarb (Auros ${ }^{\circledR} 80 \%$ p/v) and triasulfuron + prosulfocarb (Auros Plus ${ }^{\circledR}$ ) (Syngenta Agro S.A., Madrid, Spain). Analytical standards of both compounds were purchased from PESTANAL ${ }^{\circledR}$ (purity > 98.9\%) (Sigma Aldrich Química S.A., Madrid, Spain). Water solubility is 815 and $13.0 \mathrm{mg} \mathrm{L}^{-1}$ and $\log$ Kow is -0.59 and 4.48 for triasulfuron and prosulfocarb, respectively. The chemical name, structure and specifications of these compounds are included in Table S1 in Supplementary material (PPDB, 2017).

\subsection{Green compost}

A composted organic residue of vegetal origin generated from the pruning of plants and trees in parks and gardens in the city of Salamanca (Spain) was used. It was supplied by the City Council. The physicochemical characteristics of this green compost (GC) on a dry weight basis are as follows: $\mathrm{pH}$ 7.33, determined in a GC/water suspension (1:2.5); organic carbon (OC) content $9.80 \%$, determined by the modified Walkley-Black method; dissolved organic carbon (DOC) $0.353 \%$, determined in a suspension of soil in deionized water (1:2) after shaking (24 h), centrifugation (20 min at $10000 \mathrm{rpm}$ ), and filtering using a Shimadzu 5050 organic carbon analyser (Shimadzu, Columbia, MD, USA); total N $1.04 \%$, determined by the Kjeldahl method. The $\mathrm{C} / \mathrm{N}$ ratio was 9.42 , and the ash percentage determined by weight difference after ignition at $540^{\circ} \mathrm{C}$ for $24 \mathrm{~h}$ was $74.5 \%$. All parameters were determined by standard methods 
(Sparks, 1994).

\subsection{Experimental set-up}

The field experiment was conducted in an agricultural sandy clay loam soil (Typic Haploxerept) located in the Muñovela experimental farm belonging to the Institute of Natural Resources and Agrobiology of Salamanca, Spain (latitude 40 $55^{\prime} 56^{\prime \prime}$ $\mathrm{N}$, longitude $\left.5^{\circ} 52^{\prime} 53^{\prime \prime} \mathrm{W}\right)$. Rainfall and air temperature were monitored over the 100 days of experimentation at a meteorological station installed on site. An experimental layout of randomized complete blocks was designed in February 2015, with eight treatments and three replicates per treatment ( 24 plots of $3 \mathrm{~m} \times 3 \mathrm{~m}$ ) corresponding to unamended soil (12 plots) and soil amended with GC at the rate of $120 \mathrm{t} \mathrm{ha}^{-1}$ on a dry weight basis $\left(\sim 11.6 \mathrm{t} \mathrm{C} \mathrm{ha}^{-1}\right)$ (12 plots) (Figure S1 in Supplementary material). Three unamended and three amended plots were treated with single commercial formulations of each herbicide $\left(\operatorname{Logran}^{\circledR}\right.$ and Auros $\left.{ }^{\circledR}\right)$, or a combined commercial formulation of both herbicides (Auros Plus ${ }^{\circledR}$ ). Three more control plots (unamended and amended) did not receive any herbicide. Prior to amendment, the soil was tilled using a field cultivator, and then GC was manually mixed with the topsoil $(0-20 \mathrm{~cm})$ in each plot. The study was conducted in the cereal growing season, but the plots were left fallow.

\subsection{Application of herbicides}

Water-herbicide solutions were applied manually using a backpack sprayer (volume of $10 \mathrm{~L}$ ) shortly after the soil was amended. The doses applied to the plots were $4.5 \mathrm{~kg}$ i.a. ha ${ }^{-1}$ as $\operatorname{Auros}^{\circledR} 80 \%$ and 100 g i.a. ha ${ }^{-1}$ as $\operatorname{Logran}^{\circledR} 20 \%$, corresponding to the recommended application dose for prosulfocarb and double this dose for triasulfuron, respectively (De Liñán Vicente and De Liñán Carral, 2008). Similar doses of both 
compounds were applied jointly as Auros Plus ${ }^{\circledR}$. The theoretical concentrations were $0.077 \mathrm{mg} \mathrm{kg}^{-1}$ and $3.46 \mathrm{mg} \mathrm{kg}^{-1}$ for triasulfuron and prosulfocarb, respectively, calculated considering a soil density of $1.3 \mathrm{~g} \mathrm{~cm}^{-3}$ and a depth of $10 \mathrm{~cm}$, although the real concentrations measured ranged from $0.073-0.211 \mathrm{mg} \mathrm{kg}^{-1}$ and $4.56-5.22 \mathrm{mg} \mathrm{kg}^{-1}$ for both compounds, respectively, in different plots. A check was made prior to the application of the herbicides to ensure that no amounts of these compounds were detectable in the soil samples. This was as expected, because the plots had no history of triasulfuron and prosulfocarb application in the previous five years.

\subsection{Soil sampling and sample processing}

Soil samples from 0 to $10 \mathrm{~cm}$ were collected on the first day after herbicide application to determine the initial concentration of compounds, and after $2,7,9,15$, 29, 51 and 100 days after treatment to determine herbicide dissipation. Five subsamples were taken in each plot, mixing them before they were transferred to polypropylene bottles. Additionally, five soil cores were also collected in each plot to a depth of $50 \mathrm{~cm}$ at 15,30 and 100 days after application to study the herbicide's downward mobility in the soil. The cores were then sectioned into five segments of 10 $\mathrm{cm}$ each, and composite samples of five cores were transferred to a polypropylene bottle. All the samples were transported to the laboratory in portable refrigerators. The soil water content of the bulk sample for each $10-\mathrm{cm}$ soil layer was gravimetrically determined by weight difference, measuring the soil sample mass before and after drying at $110^{\circ} \mathrm{C}$ for $24 \mathrm{~h}$. Bulk density was obtained in an additional core by calculating the weight of dry soil contained in the volume $\left(31.4 \mathrm{~cm}^{3}\right)$ of a $10-\mathrm{cm}$ sampling. It ranged from 1.39 to $1.59 \mathrm{~g} \mathrm{~cm}^{-3}$ and from 1.0 to $1.59 \mathrm{~g} \mathrm{~cm}^{-3}$ in the soil profile for the unamended and amended soils, respectively. The profiles of the volumetric water content in plots with different treatments were determined from bulk density and 
gravimetric moisture content at 15, 30 and 100 days after herbicide application. Soil samples, previously air-dried overnight if necessary, were then sieved $(<2 \mathrm{~mm})$ and their characteristics determined by standard methods (Sparks, 1994) (Table 1). The pH of the soils was determined in soil/water suspensions (1:2.5), and OC and DOC were determined as previously indicated. Inorganic carbon was determined as $\mathrm{CaCO}_{3}$ with a Bernard calcimeter. Particle size distribution was determined using the pipette method, and clay minerals were identified qualitatively by the X-ray diffraction technique using a Philips PW 1710 diffractometer (Eindhoven, the Netherlands) (Robert, 1975). The Rawls pedotransfer function (Rawls et al., 1982) was used to calculate the soil water content at field capacity $\left(\theta_{\mathrm{FC}}, 33 \mathrm{kPa}\right)$ for each 10 -cm soil layer. These values vary from 0.264 to $0.294 \mathrm{~cm}^{3} \mathrm{~cm}^{-3}$ in the unamended soil profiles, and from 0.267 to $0.359 \mathrm{~cm}^{3}$ $\mathrm{cm}^{-3}$ in the amended soil profiles (Table 1).

\subsection{Herbicide extraction and analysis}

Duplicate subsamples of moist soil (6 g) from each plot were transferred to a glass tube, and extracted with methanol $(12 \mathrm{~mL})$. The samples were sonicated for $1 \mathrm{~h}$, shaken at $20^{\circ} \mathrm{C}$ for $24 \mathrm{~h}$, and then centrifuged at $5045 \mathrm{~g}$ for $15 \mathrm{~min}$. A volume of $8 \mathrm{~mL}$ was transferred to a clean glass tube and evaporated until dryness at $25^{\circ} \mathrm{C}$ under a nitrogen stream using an EVA-EC2-L evaporator (VLM GmbH, Bielefeld, Germany). The residue was dissolved in $0.5 \mathrm{~mL}$ of methanol+formic acid (1\%), filtered to remove particles $>0.45 \mu \mathrm{m}$ in a GHP Acrodisc filter (Waters Corporation), and transferred to a HPLC glass vial for analysis.

The analysis of triasulfuron and prosulfocarb was performed by HPLC. The apparatus used was a Waters chromatograph (Waters Assoc., Milford, MA, USA), equipped with a model e2695 multisolvent delivery and autosampler system attached to 
a ZQ mass spectrometer detector (MS), with Empower software as the data acquisition and processing system. A Luna ${ }^{\circledR} 3 \mu \mathrm{m} \operatorname{PFP}(2) 100 \AA(150 \times 4.6 \mathrm{~mm})$ column by Phenomenex (Torrance, CA, USA) was used at ambient temperature, and the mobile phase was acetonitrile:water $+1 \%$ formic acid (70:30). The flow rate of the mobile phase

204 was $0.4 \mathrm{~mL} \mathrm{~min}{ }^{-1}$, and the sample injection volume was $10 \mu \mathrm{L}$. Detection involved monitoring the positive molecular ion $[\mathrm{m} / \mathrm{z}] 402.8[\mathrm{M}+\mathrm{H}]^{+}$(triasulfuron) and 252.4 $[\mathrm{M}+\mathrm{H}]^{+}$(prosulfocarb) after applying an optimized cone voltage of $20 \mathrm{~V}$, and the retention times were $6.1 \mathrm{~min}$ and $14.1 \mathrm{~min}$, respectively. The matrix-matched calibration standards were between 0.1 and $2.5 \mu \mathrm{g} \mathrm{mL} \mathrm{m}^{-1}$ for both herbicides, and the limit of detection (LOD) and limit of quantification (LOQ) were in the ranges 0.018$0.026 \mu \mathrm{g} \mathrm{mL} L^{-1}$ or $0.059-0.088 \mu \mathrm{g} \mathrm{mL}^{-1}$ for triasulfuron, and $0.005-0.008 \mu \mathrm{g} \mathrm{mL}^{-1}$ or 0.017-0.027 $\mu \mathrm{g} \mathrm{mL}^{-1}$ for prosulfocarb in the unamended and amended soils, respectively (Table S2 in Supplementary material). The method's recoveries were determined by spiking three unamended and amended soil samples with triasulfuron or prosulfocarb at similar concentrations to those applied in the field, and performing the extraction procedure as described above. The mean recovery values for a level spiking of $76.9 \mu \mathrm{g}$ $\mathrm{kg}^{-1}$ of triasulfuron were $>80 \%$ when triasulfuron was applied individually (Logran ${ }^{\circledR}$ ) or in combined form (Auros Plus ${ }^{\circledR}$ ) and for a level spiking of $3.46 \mathrm{mg} \mathrm{kg}^{-1}$ of prosulfocarb were $>90 \%$ for prosulfocarb applied individually $\left(\right.$ Auros $\left.^{\circledR}\right)$ or $>80 \%$ when it was applied in combined form (Auros Plus ${ }^{\circledR}$ ) for the unamended and GC-amended soils (Table S2 in Supplementary material). These recoveries were considered acceptable according to Good Laboratory Practice (GLP) requirements for residues analysis (70-100\% recovery) (Gennari et al., 2000). The amounts of triasulfuron and prosulfocarb extracted from soils were not corrected for recovery values because matrix-matched calibration method was used. 
Furthermore, positive molecular ions $(\mathrm{m} / \mathrm{z}) 141.15[\mathrm{M}+\mathrm{H}]^{+}$(triazine amine), $388.8[\mathrm{M}+\mathrm{H}]^{+}\left(\mathrm{O}-\right.$ demethyl triasulfuron) and $267.4[\mathrm{M}+\mathrm{H}]^{+}$(prosulfocarb sulfoxide) were qualitatively monitored for the detection of triasulfuron and prosulfocarb metabolites (EFSA, 2007; EFSA 2015).

\subsection{Adsorption experiments}

The adsorption of triasulfuron and prosulfocarb by triplicate unamended and amended soils ( $5 \mathrm{~g}$ ) was determined as a single-point concentration at the beginning of the experiment. Solutions of individual or combined compounds at a concentration of $10 \mathrm{mg} \mathrm{L}^{-1}(10 \mathrm{~mL})$ were used. The suspensions were shaken intermittently at 2-3 $\mathrm{h}$ intervals for $24 \mathrm{~h}$ in a thermostated chamber at $20^{\circ} \mathrm{C}$. They were subsequently centrifuged at $5045 \mathrm{~g}$ for $15 \mathrm{~min}$, and the herbicide concentrations were determined as previously indicated. The amount of herbicide sorbed $\left(\mathrm{Cs}, \mathrm{mg} \mathrm{kg}^{-1}\right)$ was considered the difference between that initially present in the solution $\left(\mathrm{Ci}, \mathrm{mg} \mathrm{L}^{-1}\right)$ and that remaining after equilibration with the soil $\left(\mathrm{Ce}, \mathrm{mg} \mathrm{L}^{-1}\right)$. Distribution coefficients, $\mathrm{Kd}\left(\mathrm{L} \mathrm{kg}^{-1}\right)$, were calculated from the relationship between $\mathrm{Cs}\left(\mathrm{mg} \mathrm{kg}^{-1}\right)$ and $\mathrm{Ce}\left(\mathrm{mg} \mathrm{L}^{-1}\right)(\mathrm{Kd}=$ $\mathrm{Cs} / \mathrm{Ce})$.

\subsection{Data analysis}

The dissipation kinetics for both herbicides was fitted to a single first-order (SFO) kinetic model $\left(\mathrm{C}=\mathrm{C}_{0} \mathrm{e}^{-\mathrm{kt}}\right)$ or first order multicompartment (FOMC) model $(\mathrm{C}=$ $\left.\left.\mathrm{C}_{0} /(\mathrm{t} / \beta)+1\right)^{\alpha}\right)$, known also as the Gustafson and Holden model. FOCUS work group guidance recommendations were followed (FOCUS, 2006) for selecting the kinetic model that best describes the dissipation results. The coefficient of determination $\left(\mathrm{R}^{2}\right)$ and the chi-square $\left(\chi^{2}\right)$ test were calculated as indicators of the goodness of fit. The $\chi^{2}$ 
test considers the deviations between observed and calculated values relative to the uncertainty of the measurements for a specific fit, and was used to compare the goodness of fit of the two models tested. The error value at which the $\chi^{2}$ test is fulfilled at a given degree of freedom should be below 15\% (at a 5\% significance level). Values for the time to $50 \%$ dissipation $\left(\mathrm{DT}_{50}\right)$ were used to characterize the decay curves and compare variations in dissipation rates. The parameters of the kinetic models were estimated using the Excel Solver add-in package (FOCUS, 2006). soil treatment on herbicide dissipation. Standard deviation (SD) was used to indicate variability among replicates. Fisher's least significant difference (LSD) method, at a confidence level of 95\%, was determined with SPSS Statistics 22.0 software for Windows (SPSS Inc. Chicago, USA).

262

\section{Results and discussion}

\subsection{Weather conditions and soil water content}

Weather conditions were recorded throughout the experiment (100 days) (Fig.

267 the time period. Cumulative precipitation during the experiment was $118.8 \mathrm{~mm}$, but low-intensity rainfall occurred during the first 15 and 30 days $(6.4$ and $17.8 \mathrm{~mm}$ were recorded in total, respectively), corresponding to soil sampling and herbicide determination. Rainfall events > $10 \mathrm{~mm}$ occurred at 36, 47, 89 and 91 days after herbicide application.

Soil water content ranged between $0.100-0.174 \mathrm{~cm}^{3} \mathrm{~cm}^{-3}$ (soil) and $0.079-0.132$ 
sampling times. The standard deviation of the means at each depth and replicate plots was $<20 \%$, indicating close agreement between plots treated with each formulation (Fig. 2). The highest values of water content in the soil profile were, in general, observed after 15 days of treatment in the unamended plots, and after 30 days in the amended plots. On the whole, soil water content increased sharply at 20 and $30 \mathrm{~cm}$ depth in the unamended and amended plots at the different sampling times, respectively. This increase was more pronounced in the amended plots. Both unamended and amended soil profiles recorded the highest degree of soil saturation at $20-30 \mathrm{~cm}$ depth. The saturation rate of this soil layer ranged from $59 \%$ to $63 \%$ and from $46 \%$ to $63 \%$ of the soil field capacity for the unamended and GC-amended soils at the different sampling times, respectively. The application of GC to soil increased the water-holding capacity of the $20-\mathrm{cm}$ topsoil layers by between $16 \%$ and $23 \%$ (Table 1), which involved a decrease in the saturation rate of the $20-\mathrm{cm}$ topsoil layers of between $13 \%$ and $28 \%$ at the different sampling times. Changes in GC-soil water content were initially more uneven (Fig. 2), and the distribution of water in the soil profile is more likely linked to light preferential flows in the soil than in the GC-soil, at least initially. Some authors have highlighted the ability organic amendments have to improve the soil's aggregation and structural stability, and its overall porosity, as well as modify pore size and connectivity, and consequently reduce the presence of preferential flows (Ingelmo Sánchez and Rubio Delgado, 2008; Yazdanpanah et al., 2016).

\subsection{Dissipation of herbicides}

The dissipation kinetics of triasulfuron and prosulfocarb in the unamended and GC-amended soils was determined from the herbicide concentrations in soil extracts (Fig. 3 and 4). These amounts were obtained at different times until 100 days after the 
application of herbicides. They were expressed as percentages of the amounts found in the samples taken immediately after application, which were considered a reference for the herbicide applied. Herbicide concentrations were fitted to kinetic equations, and $\mathrm{DT}_{50}$ values were calculated for triasulfuron and prosulfocarb for each one of the conditions established.

\subsubsection{Triasulfuron dissipation}

Triasulfuron dissipation followed slow and prolonged dissipation kinetics until 100 days (Fig. 3). In general, the dissipation kinetics of this herbicide in the unamended and GC-amended soils fitted the single first-order (SFO) kinetic model better than the first-order multi-compartment (FOMC) kinetic model $\left(\chi^{2}\right.$ values were lower than those corresponding to the FOMC model). The kinetics of triasulfuron dissipation fitted to a SFO model have been reported by some authors in laboratory studies, whereas in field studies the kinetics are better fitted to a biphasic model (Singh and Kulshrestha, 2006; EFSA, 2015). $\mathrm{DT}_{50}$ values were obtained from these equations for triasulfuron dissipation in each one of the plots (Table 2). The results obtained were very similar in some replicate plots (coefficient of variation $(\mathrm{CV})<10 \%$ ), while they varied more in other plots $(\mathrm{CV}<25 \%)$, as expected for a field experiment. This variability did not depend on the commercial formulation applied $\left(\right.$ Logran $^{\circledR}$ or Auros Plus ${ }^{\circledR}$ ) or soil treatment. After 100 days of treatment, the residual amount of triasulfuron was $<5 \%$ in the unamended soil and $<10 \%$ in the amended one. These values indicate that the dissipation of the herbicide after 100 days of application was not complete, although it was slower in the amended soil than in the unamended one.

The $\mathrm{DT}_{50}$ mean value of triasulfuron in the unamended soil was $19.6 \pm 2.17$ days, and increased to $46.7 \pm 11.6$ days $(\mathrm{p}<0.05)$ in the GC-amended soil when applied 
325 individually $\left(\operatorname{Logran}{ }^{\circledR}\right)$. However, non-significant differences were recorded between

326 the $\mathrm{DT}_{50}$ of triasulfuron after its combined application with prosulfocarb (Auros Plus ${ }^{\circledR}$ )

327 in the unamended soil $(24.5 \pm 4.62$ days $)$ and in the amended one $(24.5 \pm 1.48$ days $)$,

328 although a lag phase was observed in the unamended soil prior to herbicide dissipation

329 when applied as Auros Plus ${ }^{\circledR}$. This phase, corresponding to the period of adaptation that

330 the microorganisms undergo before they begin to degrade the compound, has been

331 observed for other compounds (Marín-Benito et al., 2014).

332 The $\mathrm{DT}_{50}$ values found in this study are within the range observed in other field

333 studies on unamended soils (<50 days) (Sarmah et al., 2000; EFSA, 2015), but they are

334 lower than those obtained in laboratory experiments (33-76 days) (James et al., 1999;

335 EC, 2000; Pose-Juan et al., 2017). Mobility into deeper layers was one the factors

336 proposed for trisulfuron increased dissipation in the field. Triasulfuron is a weak

337 organic acid, and the variable dissipation data could be explained by the influence of $\mathrm{pH}$

338 and other environmental factors, such as OM content or water content, in this

339 herbicide's availability and dissipation (Pinna et al., 2009). On the other hand,

340 triasulfuron degradation may be expected, although the transformation products

341 described, such as triazine amine or demethyl triasulfuron (EFSA, 2015), were not

342 found here.

343 The results indicating the increased $\mathrm{DT}_{50}$ values of triasulfuron in the GC-

344 amended soil are in agreement with the adsorption coefficients $\mathrm{K}_{\mathrm{d}}$ of triasulfuron for the

345 soil+GC $\left(0.53 \mathrm{~mL} \mathrm{~g}^{-1}\right)$ (Table S3, in Supplementary material), and higher than in the

346 unamended soil $\left(0.05 \mathrm{~mL} \mathrm{~g}^{-1}\right)$. An increased adsorption of this herbicide by soils

347 amended with different composted organic residues has also been reported in laboratory

348 studies (Said-Pullicino et al., 2004; Pose-Juan et al., 2017). However, the addition of

349 straw residues as organic amendment increased the dissipation of triasulfuron in lab 
experiments, but not in the field (Menne and Berger, 2001). The application of compost to the soil only influenced the dissipation of triasulfuron when it was applied individually, but not when applied as a combined formulation. Compost provides soils with OC and microorganisms that are capable of modifying the bioavailability of herbicides, possibly leading to increased or decreased dissipation (Barriuso et al., 1997). The results obtained could be explained by considering that in the presence of prosulfocarb (Table S3) the adsorption of triasulfuron by the unamended soil increased, and decreased for the amended soil $\left(\mathrm{Kd}=0.31\right.$ and $0.38 \mathrm{~mL} \mathrm{~g}^{-1}$, respectively). The combined application of herbicides could have a mutual influence on the behaviour of herbicides and on their own transformation rate (Menne and Berger; 2001). Both positive and negative effects due to the interactions of the compounds and microorganisms have been described, and may explain the results obtained when the combined formulation was applied (Fogg et al., 2003).

\subsubsection{Prosulfocarb dissipation}

Prosulfocarb followed biphasic kinetics; the first phase was rapid, and was followed by a slow and prolonged phase until 100 days (Fig. 4). These biphasic dissipations have frequently been observed for pesticides with different hydrophobic character (Rodríguez-Liébana et al., 2017). The dissipation kinetics of this herbicide fitted a SFO kinetic model in the unamended soil, and in general fitted a FOMC kinetic model in the GC-amended soil (Table 2) according to $\chi^{2}$ values. The fitting of

371 prosulfocarb dissipation in the unamended soil to a SFO model has also been reported

372 by laboratory and field experiments (Rouchaud et al., 1997; Gennari et al., 1998; EFSA, 2007). The concentrations of herbicide decreased continuously in the second-phase until the last sampling after 100 days of treatment. Almost complete dissipation occurred in 
both the unamended and amended soils at this time, but there were still detectable amounts. A minimum residual concentration of prosulfocarb was found in the topsoil for all treatments $(<0.5 \%$ in the unamended soil and $<2 \%$ in the amended soil).

The dissipation of prosulfocarb was more rapid than that of triasulfuron, and the $\mathrm{DT}_{50}$ values of prosulfocarb ranged between $14.6 \pm 3.06$ to $18.5 \pm 5.59$ days in the unamended soil and between $14.2 \pm 5.59$ to $13.9 \pm 3.10$ days in the amended soil when a single or combined application with triasulfuron was used (Table 2). The $\mathrm{DT}_{50}$ values obtained here are within the range of those found in field experiments in unamended soils (EFSA, 2007, range 6.3-38.4 days in soil with $\mathrm{pH}$ 4.8-7.5, and OC 0.7-3.1\%). Gennari et al. (1998) have reported that the $\mathrm{DT}_{50}$ values of prosulfocarb in three soils are inversely related to soil OM content. However, this was not observed here, although the adsorption of prosulfocarb by the GC-amended soil was higher than that by the unamended soil, as indicated by the $\mathrm{K}_{\mathrm{d}}$ values of 37.2 and $24.1 \mathrm{~mL} \mathrm{~g}^{-1}$, respectively (Table S3). The results indicate that the dissipation rate was not significantly different for the three replicate plots, and non-significant differences were also observed between prosulfocarb dissipation in plots of unamended or amended soils when it was applied as Auros ${ }^{\circledR}$ or as Auros Plus ${ }^{\circledR}$.

The rapid decrease in herbicide concentration in the surface soil observed in the first phase may be attributed to the transformation of the compound or bound residue formation in soils due to the high adsorption by soil OC (Gennari et al., 2002; Nègre et al., 2006; EFSA, 2007) or mobility in the soil profile. Some traces of prosulfocarb sulfoxide were detected in both the unamended and amended soils (data not shown), confirming the evidence reported on the microbial degradation of prosulfocarb (Gennari et al., 2002; EFSA, 2007). On the other hand, non-extractable bound residues could also form in the soil, as this has been considered the main cause of the dissipation of some 
hydrophobic compounds (Marin-Benito et al., 2014). However, the strongly adsorbed fraction of herbicide in the soil profile could also be mobile over time, as observed for other hydrophobic compounds in field dissipation studies (Herrero-Hernández et al., 2011, 2015).

\subsection{Mobility of herbicides}

The mobility of triasulfuron and prosulfocarb through the soil profile was verified in the unamended and GC-amended soil plots (Fig. 5 and 6) through the analysis of different soil depths $(0-50 \mathrm{~cm})$ after 15, 30 and 100 days of herbicide application.

\subsubsection{Triasulfuron mobility}

Triasulfuron mobility with the wetting front could be expected in the soil profile, as it has been reported that sulfonylureas adsorption decreases when soil $\mathrm{pH}$ increases (Pusino et al., 2003). This particularly occurs in soils with $\mathrm{pH}>\mathrm{pKa}$ of compounds when they are in anionic form. The $\mathrm{pH}$ of the unamended and amended soils in the experimental plots was always $>7$ (Table 1 ), which means triasulfuron could be mobile with the wetting front of water because its $\mathrm{pKa}$ is 4.64 . In this work, triasulfuron was mobile up to $50 \mathrm{~cm}$, in agreement with other studies that have reported leaching and persistence of this herbicide in soils ranging from acid to slightly alkaline (Sarmah et al., 2000). The residual amount of triasulfuron applied as Logran ${ }^{\circledR}$ in the top layer of the unamended soil was $0.079 \mu \mathrm{g} \mathrm{g}^{-1}$ after 15 days of treatment $(>50 \%$ of the amount initially determined and taken as application reference). Similar behaviour was observed after 30 days of treatment, although residual amounts decreased at all depths. At the end of the experiment, a significant decrease in herbicide residues was observed in all the soil profile, and an amount of $0.003 \mu \mathrm{g} \mathrm{g}^{-1}$ was found in the top layer. Triasulfuron 
mobility followed a similar pattern in both the GC-amended soil and in the unamended one, although the residual amounts after 15 days of treatment were lower than in the unamended soil, with $0.049 \mu \mathrm{g} \mathrm{g}^{-1}$ in the top layer. However, after 30 days of treatment the residual amounts increased at a depth of $30 \mathrm{~cm}$, probably due to the sharp increase in the soil water content observed mainly for the amended soils at this depth, which would have facilitated the downwards movement of the herbicide (Fig. 2). The interaction in solution between triasulfuron and DOC derived from GC may decrease solute sorption and increase the mobility of this herbicide (highly soluble in water) in amended soils as reported for other pesticides (Álvarez-Martín et al., 2017; MarínBenito et al., 2013; Rodríguez-Liébana et al. 2018). At the end of experiment, an amount of $0.006 \mu \mathrm{g} \mathrm{g}^{-1}$ was found in the top layer.

The herbicide concentrations on the soil surface decreased over time compared to those recorded immediately after its application, doing so to a greater extent in the unamended soil (43.2-97.8\%) than in the amended one (32.8-92.1\%). A lower adsorption of triasulfuron by the unamended soil (Table S3), together with a higher water saturation rate of the unamended soil profile previously indicated at this time (Table 1) could lead to a higher initial leaching of triasulfuron. An amount of $0.002 \mu \mathrm{g}$ $\mathrm{g}^{-1}$ reached a depth of $30-40 \mathrm{~cm}$ after 15 days of application in the unamended soil, while the leaching of triasulfuron in the amended soil only reached this depth after 100 days of application. The water saturation rate of the GC-soil profile, which was higher at this time than at 15 days, could also explain this behaviour. The application of GC to the soil prevented the rapid leaching of triasulfuron, although it lasted longer in the topsoil and in the soil profile. Triasulfuron concentrations were found down to 30-40 $\mathrm{cm}\left(0.0003 \mu \mathrm{g} \mathrm{g}^{-1}\right)$ in the amended soil profile after 100 days of treatment, while residual amounts were detected only as far as $10-20 \mathrm{~cm}\left(0.0007 \mu \mathrm{g} \mathrm{g}^{-1}\right)$ in the 
unamended soil at this time. A low correlation was found between the adsorption constants of triasulfuron and the OC content of the soil profile $(\mathrm{p}<0.1)$, although GC increased its adsorption in the top layer.

In spite of the clay texture of this soil, the anomalous peaks of the herbicide residues at deeper soil layers, which are indicators of preferential flows reported for other sulfonylureas, were not observed here (Sarmah et al., 2000). This means the presence of triasulfuron in the unamended soil profile in deeper layers at 15 days than at 100 days was not determined mainly by preferential flows, but agreed with the varying extent of water infiltration observed at both times.

The behaviour of triasulfuron applied as Auros Plus ${ }^{\circledR}$ followed a similar pattern, again recording the highest residual amounts in the top of the initially unamended soils $\left(0.144 \mu \mathrm{g} \mathrm{g}^{-1}\right)$ (Fig. 5). Herbicide concentrations on the soil surface also decreased over time from those recorded immediately after its application. However, in this case, a greater decrease was generally observed in the amended soils $(35.3-90.6 \%)$ than in the unamended ones (22.0-97.6\%). The results indicate that the highest amounts of triasulfuron were leached after 30 days of application in both unamended and amended soils, when triasulfuron concentrations were found in the soil profile up to a depth of 40-50 $\mathrm{cm}$ in both the unamended soil $\left(0.003 \mu \mathrm{g} \mathrm{g}^{-1}\right)$ and the amended one $\left(0.001 \mu \mathrm{g} \mathrm{g}^{-}\right.$ ${ }^{1}$ ). The adsorption coefficient $\mathrm{K}_{\mathrm{d}}$ of triasulfuron together with prosulfocarb (Auros Plus ${ }^{\circledR}$ ) by unamended soil increased, but decreased for the amended soil (Table S3) compared to the adsorption of the individual compound. This is consistent with the increased persistence of triasulfuron applied jointly with prosulfocarb in the unamended soil and its decreased persistence in the GC-amended soil compared to its single application. No significant correlation was found between the adsorption coefficients $K_{d}$ and the OC content of the soil profile and the delayed leaching of triasulfuron until 30 
475 days could be explained by a synergic effect of the mixed formulation. dos Reis et al.

476 (2017) have reported a competitive effect for adsorption sites to explain the application

477 method's influence on the leaching of certain herbicides.

In this field study changes in $\mathrm{pH}$ values were not observed and neither

herbicide degradation was observed as reported in other studies (Walker and Welch 1989). Other parameters, such as the different water saturation rates of the unamended and amended soil profiles, and the consequent different extent of water infiltration, might have contributed to the variable leaching behaviour of triasulfuron over time. It is remarkable that a rapid increase in soil water content was seen in depths of up to $30 \mathrm{~cm}$ after 30 days of herbicide application in the unamended soil, while the water content was initially less variable in the amended soil profile (Fig. 2). However, the presence of triasulfuron residues up to depths of $40-50 \mathrm{~cm}$ confirms the mobility of the herbicide down through the profile by increasing its water solubility.

\subsubsection{Prosulfocarb mobility}

The residual amount of prosulfocarb found in the unamended topsoil was 2.376 $\mu \mathrm{g} \mathrm{g}^{-1}$ after 15 days of its application as Auros ${ }^{\circledR}$ treatment, and it decreased to $0.018 \mu \mathrm{g}$ $\mathrm{g}^{-1}$ at the end of the experiment. In general, the amounts recorded were higher in the soils amended with GC (3.148 and $0.526 \mu \mathrm{g} \mathrm{g}^{-1}$ after 15 or 100 days of application) than in the unamended one (Fig. 4). The highest prosulfocarb retention was recorded at a depth of 0-10 cm, and concentrations decreased over time compared to those recorded immediately after its application, doing so to a greater extent in the unamended soil 497 (54.6-99.7\%) than in the amended one (47.7-98.0\%). The results agree with the adsorption coefficients $\mathrm{K}_{\mathrm{d}}$ previously indicated (Table S3). However, a higher initial 
leaching of prosulfocarb was recorded in the amended soil, reaching a depth of 40-50

$500 \mathrm{~cm}\left(0.029 \mu \mathrm{g} \mathrm{g}^{-1}\right)$ after 15 days of application, while in the unamended soil the herbicide 501 reached down to $40-50 \mathrm{~cm}\left(0.101 \mu \mathrm{g} \mathrm{g}^{-1}\right)$ after 30 days of application. The GC soil amendment increased the persistence of prosulfocarb in the soil, but leaching was not 503 inhibited, with this compound being detected through the soil profile up to 100 days 504 after the application in both the unamended and amended soils $\left(0.0024\right.$ and $0.0007 \mu \mathrm{g} \mathrm{g}^{-}$ $505{ }^{1}$ were recorded at $40-50 \mathrm{~cm}$, respectively). The water saturation rate of the unamended 506 and amended soil profiles, which were the same as for triasulfuron, do not explain the behaviour of prosulfocarb, which is a very hydrophobic compound. While, the DOC content of the amendment (range $0.015-0.019 \%$ over time) could affect the mobility of prosulfocarb in the amended soil profile. The adsorption of pesticides by DOC has been described in many papers in laboratory and field studies (Álvarez-Martín et al., 2017; Marín-Benito et al., 2013; Rodríguez-Liébana et al., 2018). This process has its effect on the mobility of pesticides in soils (Marín-Benito et al., 2016), and it could explain the leaching of prosulfocarb in spite of the rapid adsorption and/or dissipation in soil

514 found here and in other papers (Braun et al., 2017) and its low-to-moderate potential for 515 mobility in soil (EFSA, 2007). The results obtained show how GC initially increased herbicide retention on the surface, and a significant correlation was also found between

517 the adsorption coefficients $\mathrm{K}_{\mathrm{d}}$ of prosulfocarb by soil profile layers and each layer' OC content $(\mathrm{r}=0.99, \mathrm{p}<0.01)$ (Nègre et al., 2006), although the herbicide's mobility could 519 be enhanced over time at even deeper soil layers in amended soils.

The behaviour of prosulfocarb applied in combination with triasulfuron as Auros

521 Plus ${ }^{\circledR}$ initially followed a different pattern to the single formulation with the highest residual amounts recorded in the unamended soils (Fig. 6). The herbicide concentrations in the soil surface decreased over time compared to those recorded immediately after 
524 application, but contrary to the Auros ${ }^{\circledR}$ treatment, it decreased more in the amended soil

$525(52.1-97.9 \%)$ than in the unamended one (43.0-99.3\%). The results indicate that the 526 amounts of leached prosulfocarb obtained after 15 or 30 days of application were 527 similar to those obtained when Auros ${ }^{\circledR}$ was applied, with the highest amounts leached 528 after 30 days of application in both unamended and amended soils. Residues of 529 prosulfocarb were found after 100 days at a depth of $50 \mathrm{~cm}$ at levels of $0.002 \mu \mathrm{g} \mathrm{g}^{-1}$.

530 The adsorption coefficients $\mathrm{K}_{\mathrm{d}}$ of prosulfocarb as Auros Plus ${ }^{\circledR}$ for the unamended soil

531 (21.6 $\left.\mathrm{g} \mathrm{mL}^{-1}\right)$ and the amended one $\left(30.7 \mathrm{~g} \mathrm{~mL}^{-1}\right)$ decreased with respect to the $\mathrm{K}_{\mathrm{d}}$ 532 values of prosulfocarb as Auros ${ }^{\circledR}$, but the herbicide's leaching behaviour was generally 533 similar when applied as a single or combined formulation.

\section{Conclusions}

Our results show how GC decreases the dissipation of triasulfuron applied as an individual formulation due to the herbicide's increased adsorption in an amended soil. This effect was not seen when triasulfuron was applied as a combined formulation. The dissipation of prosulfocarb was more rapid than that of triasulfuron, and no significant 540 differences were found under the different conditions studied. An irreversible adsorption of prosulfocarb by both unamended and amended soil could explain this result compared to triasulfuron, given the more hydrophobic nature of prosulfocarb. The mobility of herbicides through the soil profile was confirmed by the greater amounts of

544 residues detected in the $0-10 \mathrm{~cm}$ layer for both herbicides and for all treatments at the 545 different sampling times. However, relevant concentrations at 10-20 cm layers were 546 also detected for triasulfuron under all conditions, with small concentrations for 547 prosulfocarb in the GC-amended soil. GC decreased the leaching of triasulfuron applied 548 as a single formulation, but not when applied as a combined formulation with 
prosulfocarb. No effect was observed for the single or combined formulations of prosulfocarb. The extent of triasulfuron leaching was closely linked to the extent of water infiltration, but this was not the case for prosulfocarb. The mobility of both herbicides throughout the soil profile might have been influenced by DOC derived from GC. The interest of these results is sustained considering leaching of herbicides from the soil surface shortens the duration of residual weed control, and may contaminate groundwater. On the other hand, the amounts retained in the soil profile could exceed the recorded threshold for the sensitivities of susceptible species. Further studies for a longer period are required to establish the influence of new agricultural practices in herbicide behaviour in order to improve their efficacy and environmental impact.

\section{Acknowledgments}

This work was funded by the Regional Government Junta de Castilla y León (project CSI240U14). V.B. and J.M.M.B. thank "Junta de Castilla y León” and MINECO by their predoctoral and postdoctoral "Juan de la Cierva-Incorporación” (JCI-2014-19538) contracts, respectively.

Conflicts of Interest: The authors declare no conflict of interest.

\section{References}

569 Álvarez-Martín, A., Sánchez-Martín, M.J., Ordax, J.M., Marín-Benito, J.M., Rodríguez-

570 Cruz, M.S., 2016. Leaching of two fungicides in spent mushroom substrate amended soil: Influence of amendment rate, fungicide aging and flow condition. Sci. Total Environ. 584-585, 828-837.

573 Barriuso, E., Houot, S., Serra-Wittling, C., 1997. Influence of compost addition to soil 
on the behavior of herbicides. Pestic. Sci. 49, 65-75.

575 Braun, K.E., Luks, A.K., Schmidt, B., 2017. Fate of the ${ }^{14}$ C labeled herbicide 576 prosulfocarb in a soil and in a sediment-water system. J. Environ. Sci. Health B, 52, 122-130.

Busi, R., Powles, S.B., 2016. Cross-resistance to prosulfocarb $+S$-metolachlor and pyroxasulfone selected by either herbicide in Lolium rigidum. Pest. Manag. Sci. 72, $1664-1672$.

De Liñán Vicente C., De Liñán Carral C., 2008. Vademécum de productos fitosanitarios y nutricionales. Ediciones Agrotécnicas S.L., Madrid (Spain).

dos Reis, F.C., Tornisielo, V.L., Pimpinato, R.F., Martins, B.A.B., Filho, R.V., 2017. Leaching of diuron, hexazinone, and sulfometuron-methyl applied alone and in mixture in soils with contrasting textures. J. Agric. Food Chem. 65, 2645-2650.

EFSA (European Food Safety Authority), 2007. Conclusion on the peer review of prosulfocarb. Scientific Report 111, 1-81.

EFSA (European Food Safety Authority), 2015. Conclusion on the peer review of the pesticide risk assessment of the active substance triasulfuron. EFSA Journal 13, $3958,78 p p$.

EC (European Commission. Directorate-General Health \& Consumer Protection), 2000. Review report for the active substance triasulfuron. 33pp.

FOCUS, 2006. Guidance Document on estimating persistence and degradation kinetics

597 Fogg, P., Bowall, A.B.A., Walker, A., 2003. Degradation of pesticides in biobeds: The 598 effect of concentration and pesticide mixtures. J. Agric. Food Chem. 51, 5344-5349. 
599 García Izquierdo, C., Lobo Bedmar, M.C., 2008. Rehabilitación de suelos degradados y 600 contaminados mediante la aplicación de compost, in: Moreno Casco, J., Moral 601 Herrero, R. (Eds.), Compostaje, Mundi Prensa, Madrid, pp. 425-448.

602 Gennari M., Abbate, C., Baglieri A., Nègre, M., 2008. Fate and degradation of 603 triasulfuron in soil and water under laboratory conditions. J. Environ. Sci. Health B $604 \quad 43,498-505$.

605 Gennari, M., Ambrosoli, R., Nègre, M., Minati, J.L., 2002. Bioavailability and 606 biodegradation of prosulfocarb in soil. J. Environ. Sci. Health B 37, 297-305.

607

Gennari, M., Ferraris, L., Nègre, M., Ambrosoli, R., 1998. Behaviour of prosulfocarb in 608 three Italian soils. Fresenius Environ. Bull. 7, 688-694.

Gennari, M., Ferraris, L., Nègre, M., Cignetti, A., 2000. Liquid chromatographic 610 determination of triasulfuron in soil. J. AOAC Int. 83, 1076-1081.

Herrero-Hernández, E., Andrades, M.S., Marín-Benito, J.M., Sánchez-Martín, M.J., Rodríguez-Cruz. M.S., 2011. Field-scale dissipation of tebuconazole in a vineyard soil amended with spent mushroom substrate and its potential environmental impact. Ecotoxicol. Environ. Saf. 74, 1480-1488.

Herrero-Hernández, E., Marín-Benito, J.M., Andrades, M.S., Sánchez-Martín, M.J., 616 Rodríguez-Cruz, M.S., 2015. Field versus laboratory experiments to evaluate the fate of azoxystrobin in an amended vineyard soil. J. Environ. Manag. 163, 78-86.

Ingelmo Sánchez, F., Rubio Delgado, J., 2008. Efecto de la aplicación del compost sobre las propiedades físicas y químicas del suelo, in: Moreno-Casco, J., MoralHerrero, R., (Eds.), Compostaje, Mundi-Prensa, Madrid, Spain, pp 305-328.

James, T.K., Holland, P.T., Rahman, A., Lu, Y.R., 1999. Degradation of the sulfonylurea herbicide chlorsulfuron and triasulfuron in a high-organic matter volcanic soil. Weed Res. 39, 137-147. 
Keren, Y., Borisover, M., Schaumann, G.E., Diehl, D. Tamimic, N., Bukhanovskya, N., 2017. Land disposal of olive mill wastewater enhances ability of soil to sorb diuron: Temporal persistence, and the effects of soil depth and application season. Agric. Ecosys. Environ. 236, 43-51.

Marín-Benito, J.M., Andrades, M.S., Sánchez-Martín, M.J., Rodríguez-Cruz, M.S., 2012. Dissipation of fungicides in a vineyard soil amended with different spent mushroom substrates. J. Agric. Food Chem. 60, 6936-6945.

Marín-Benito, J.M., Brown, C.D., Herrero-Hernández, E., Arienzo, M., SánchezMartín, M.J., Rodríguez-Cruz, M.S., 2013. Use of raw or incubated organic wastes as amendments in reducing pesticide leaching through soil columns. Sci. Total Environ. 463-464, 589-599.

Marín-Benito, J.M., Herrero-Hernández, E., Andrades, M.S., Sánchez-Martín, M.J., Rodríguez-Cruz, M.S., 2014. Effect of different organic amendments on the dissipation of linuron, diazinon and myclobutanil in an agricultural soil incubated for different time periods. Sci. Total Environ. 476-477, 611-621.

Marín-Benito, J.M., Sánchez-Martín, M.J., Rodríguez-Cruz, M.S., 2016. Impact of spent mushroom substrates on the fate of pesticides in soil, and their use for preventing and/or controlling soil and water contamination: A review. Toxics 4, 17.

Menne, H.J., Berger, B.M., 2001. Influence of straw management, nitrogen fertilization and dosage rates on the dissipation of five sulfonylureas in soil. Weed Res. 41, 229244.

Nègre, M., Passarella, I., Boursier, C., Mozzetti, C., Gennari, M., 2006. Evaluation of the bioavailability of the herbicide prosulfocarb through adsorption on soils and model colloids, and through a simple bioassay. Pest Manag. Sci. 62, 957-964.

Pinna, M.V., Giunta, F., Nardi, S., Pusino, A., 2009. Effects of a municipal sewage 
sludge amendment on triasulfuron soil sorption and wheat growth. J. Agric. Food Chem. 57, 11249-11253.

651

652

653

654

655

656

657

658

659

660

661

662

663

664

665

666

667

668

669

670

671

672

673

Pose-Juan, E., Igual, J.M., Sánchez-Martín, M.J., Rodríguez-Cruz, M.S., 2017. Influence of herbicide triasulfuron on soil microbial community in an unamended soil and a soil amended with organic residues. Front. Microbiol. 8, 378.

PPDB, 2017. Pesticide Properties Data Base. University of Hertfordshire. http://sitem.herts.ac.uk/aeru/ppdb/en/index.htm.

Pusino, A., Fiori, M.G., Braschi, I., Gessa, C., 2003. Adsorption and desorption of triasulfuron by soil. J. Agric. Food Chem. 51, 5350-5354.

Rawls, W.J., Brakensiek, D.L., Saxton, K.E., 1982. Estimation of soil water properties. Trans. ASAE 25, 1316-1320.

Robert, M., 1975. Principes de determination qualitative des mineraux argileux a l'aide des rayons X. An. Agron. 26, 363-399.

Rodríguez-Liébana, J.A., El Gouzi, S., Mingorance, M.D., Castillo, A., Peña, A., 2014. Irrigation of a Mediterranean soil under field conditions with urban wastewater: Effect on pesticide behavior. Agric. Ecosys. Environ. 185, 176-185.

Rodríguez-Liébana, J.A., El Gouzi, S., Peña, A., 2017. Laboratory persistence in soil of thiacloprid, pendimethalin and fenarimol incubated with treated wastewater and dissolved organic matter solutions. Contribution of soil biota. Chemosphere 181, 508-517.

Rodríguez-Liébana, J.A., Mingorance, M.D., Peña, A., 2018. Thiacloprid adsorption and leaching in soil: Effect of the composition of irrigation solutions. Sci. Total Environ. 610-611, 367-376.

Rouchaud, J., Neus, O., Callens, D., Bulcke, R., 1997. Enhanced biodegradation of prosulfocarb herbicide in barley crop. Bull. Environ. Contam. Toxicol. 58, 752-757. 
674 Said-Pullicino, D., Gigliotti, G., Vella, A.J., 2004. Environmental fate of triasulfuron in 675 soils amended with municipal waste compost. J. Environ. Qual. 33, 1743-1751.

676 Sarmah, A.K., Kookana, R.S., Alston, A.M., 2000. Leaching and degradation of 677 triasulfuron, metsulfuron-methyl, and chlorsulfuron in alkaline soil profiles under 678 field conditions. Aust. J. Soil Res. 38, 617-631.

679 Sarmah, A.K., Kookana, R.S., Alston, A.M., 1998. Fate and behaviour of triasulfuron, 680 metsulfuron-methyl, and chlorsulfuron in the Australian soil environment: a review. Aust. J. Agric. Res. 49, 775-790.

Scotti, R., Bonanomi, G., Scelza, R., Zoina, A., Rao, M.A., 2015. Organic amendments 683 as sustainable tool to recovery fertility in intensive agricultural systems. J. Soil Sci. Plant Nut. 15, 333-352.

Singh, S.B., Kulshrestha, G., 2006. Soil persistence of triasulfuron herbicide as affected 686 by biotic and abiotic factors. J. Environ. Sci. Health B 41, 635-645.

Sofo, A., Scopa, A., Dumontet, S., Mazzatura, A., Pasquale, V., 2012. Toxic effects of 688 four sulphonylureas herbicides on soil microbial biomass. J. Environ. Sci. Health B 47, 653-659.

Sparks, D.L., 1996. Methods of Soil Analysis. Part 3-Chemical Methods. Soil Science 691

Walker, A., Welch, S.J., 1989. The relative movement and persistence in soil of Swarcewicz, M., Gregorczyk, A., Sobczak, J., 2013. Comparison of linuron degradation in the presence of pesticide mixtures in soil under laboratory conditions. Environ.

697 Yazdanpanah, N., Mahmoodabadi, M., Cerdà, A., 2016. The impact of organic 698 amendments on soil hydrology, structure and microbial respiration in semiarid lands. 
Geoderma, 266, 58-65.

700 
Figure 1. Rainfall and temperature evolution over time of experiment.

704

705

706

707

708

709

710

711

712

713

714

715

716

717

718

719

720

721

722

723

Figure 2. Mean values of soil water content of the soil profile corresponding to plots of unamended soil (A) and green compost amended soil (B) at different sampling times. Error bars represent the standard deviation of the mean values of plots treated with different herbicide formulations $(n=3)$, note that they are smaller than the symbol.

Figure 3. Dissipation of triasulfuron applied as single formulation (Logran ${ }^{\circledR}$ ) or combined formulation with prosulfocarb (Auros Plus ${ }^{\circledR}$ ) in the replicate plots of unamended soil and green compost amended soil. Error bars represent the standard deviation of the mean values for each plot $(n=2)$.

Figure 4. Dissipation of prosulfocarb applied as single formulation (Auros ${ }^{\circledR}$ ) or combined formulation with triasulfuron (Auros $\mathrm{Plus}^{\circledR}$ ) in the replicate plots of unamended soil and green compost amended soil. Error bars represent the standard deviation of the mean values for each plot $(n=2)$.

Figure 5. Distribution profiles of triasulfuron applied as single formulation $\left(\operatorname{Logran}{ }^{\circledR}\right)$ or combined formulation with prosulfocarb (Auros Plus ${ }^{\circledR}$ ) in the replicate plots of unamended soil $(\mathrm{A}, \mathrm{C})$ and green compost amended soil $(\mathrm{B}, \mathrm{D})$ after different treatment times. Error bars represent the standard deviation of the mean values of plots treated with different herbicide formulations $(n=3)$.

Figure 6. Distribution profiles of prosulfocarb applied as single formulation (Auros ${ }^{\circledR}$ ) or combined formulation with triasulfuron (Auros Plus ${ }^{\circledR}$ ) in the replicate plots of unamended soil $(\mathrm{A}, \mathrm{C})$ and green compost amended soil $(\mathrm{B}, \mathrm{D})$ after different treatment 
724 times. Error bars represent the standard deviation of the mean values of plots treated

725 with different herbicide formulations $(n=3)$. 
Table 1.

Properties of the unamended soil and green compost amended soil from experimental plots.

\begin{tabular}{|c|c|c|c|c|c|}
\hline \multirow[b]{2}{*}{ Properties } & \multicolumn{5}{|c|}{ Soil depth $(\mathrm{cm})$} \\
\hline & $0-10$ & $10-20$ & $20-30$ & $30-40$ & $40-50$ \\
\hline Soil texture & $\begin{array}{l}\text { Sandy clay } \\
\text { loam }\end{array}$ & $\begin{array}{l}\text { Sandy clay } \\
\text { loam }\end{array}$ & $\begin{array}{l}\text { Sandy clay } \\
\text { loam }\end{array}$ & $\begin{array}{l}\text { Sandy clay } \\
\text { loam }\end{array}$ & Sandy clay \\
\hline \multirow[t]{2}{*}{$\mathrm{pH}$} & $7.81^{\mathrm{a}}$ & 7.63 & 7.51 & 7.45 & 7.42 \\
\hline & $7.13-7.39^{b}$ & $7.15-7.44$ & $7.26-7.48$ & $7.49-7.55$ & $7.34-7.43$ \\
\hline \multirow[t]{2}{*}{ Bulk density $\left(\mathrm{g} \mathrm{cm}^{-3}\right)$} & $1.39^{\mathrm{a}}$ & 1.42 & 1.49 & 1.49 & 1.59 \\
\hline & $1.00^{\mathrm{b}}$ & 1.00 & 1.49 & 1.49 & 1.59 \\
\hline \multirow[t]{2}{*}{$\mathrm{OC}(\%)$} & $1.30^{\mathrm{a}}$ & 1.13 & 0.86 & 0.70 & 0.50 \\
\hline & $2.21-2.36^{\mathrm{b}}$ & $1.25-1.69$ & $0.90-0.93$ & $0.75-0.79$ & $0.53-0.54$ \\
\hline \multirow[t]{2}{*}{ DOC (\%) } & $0.002^{\mathrm{a}}$ & - & - & - & - \\
\hline & $0.015-0.019^{\mathrm{b}}$ & - & - & - & - \\
\hline \multirow[t]{2}{*}{$\mathrm{N}(\%)$} & $0.14^{\mathrm{a}}$ & 0.11 & 0.09 & 0.08 & 0.07 \\
\hline & $0.23-0.25^{\mathrm{b}}$ & $0.13-0.14$ & $0.10-0.10$ & $0.08-0.08$ & $0.07-0.07$ \\
\hline \multirow[t]{2}{*}{$\mathrm{C} / \mathrm{N}$} & $9.28^{\mathrm{a}}$ & 10.3 & 9.56 & 7.50 & 6.71 \\
\hline & $9.44-9.61^{b}$ & $9.62-12.1$ & $9.30-11.3$ & $9.38-9.88$ & $7.71-7.57$ \\
\hline $\mathrm{CaCO}_{3}(\%)$ & $0.21^{\mathrm{a}}$ & 0.18 & 0.20 & 0.22 & 0.22 \\
\hline Sand $(\%)$ & $57.63^{\mathrm{a}}$ & 58.22 & 59.15 & 55.63 & 51.04 \\
\hline Silt (\%) & $16.97^{\mathrm{a}}$ & 16.95 & 16.95 & 16.77 & 17.60 \\
\hline Clay $(\%)$ & $24.98^{\mathrm{a}}$ & 25.25 & 25.25 & 29.10 & 34.72 \\
\hline Clay mineralogy & $\mathrm{K}, \mathrm{I}, \mathrm{M}^{\mathrm{c}}$ & $\mathrm{K}, \mathrm{I}, \mathrm{M}$ & $\mathrm{K}, \mathrm{I}, \mathrm{M}$ & $\mathrm{K}, \mathrm{I}, \mathrm{M}$ & $\mathrm{K}, \mathrm{I}, \mathrm{M}$ \\
\hline \multirow[t]{2}{*}{$\theta_{\mathrm{FC}}\left(\mathrm{cm}^{3} \mathrm{~cm}^{-3}\right)^{\mathrm{d}}$} & $0.291^{\mathrm{a}}$ & 0.282 & 0.264 & 0.280 & 0.294 \\
\hline & $0.359^{\mathrm{b}}$ & 0.326 & 0.267 & 0.282 & 0.296 \\
\hline \multirow[t]{2}{*}{$\begin{array}{l}\text { Soil water content } \\
\left(\mathrm{cm}^{3} \mathrm{~cm}^{-3}\right)\end{array}$} & $0.117-0.167^{\mathrm{a}}$ & $0.157-0.161$ & $0.156-0.167$ & $0.153-0.166$ & $0.157-0.161$ \\
\hline & $0.085-0.128^{b}$ & $0.093-0.120$ & $0.123-0.167$ & $0.116-0.158$ & $0.128-0.162$ \\
\hline
\end{tabular}

${ }^{\mathrm{a}}$ Unamended soil and ${ }^{\mathrm{b}}$ Soil amended with green compost at $120 \mathrm{t} \mathrm{ha}^{-1}$. ${ }^{\mathrm{c}} \mathrm{K}$, kaolinite; I, illite; M, montmorillonite. ${ }^{\mathrm{d}}$ Volumetric water content at field capacity $(33 \mathrm{kPa})$ estimated from Rawls et al. (1982). Note: The ranges of values included for some parameters correspond to the variation of mean values of these parameters in three replicate plots at different sampling times. DOC only was determined at 0-10 $\mathrm{cm}$ soil depth. 


\section{Table 2.}

Kinetic parameters for the dissipation of triasulfuron and prosulfocarb in unamended soil and green compost amended soil treated with individual or combined formulations of herbicides, obtained from fitting kinetics to a single first-order (SFO) and first order multicompartment (FOMC) models.

\begin{tabular}{|c|c|c|c|c|c|c|c|}
\hline \multirow{2}{*}{$\begin{array}{l}\text { Herbicide } \\
\text { (Formulation) }\end{array}$} & \multirow[t]{2}{*}{ Plot } & \multicolumn{3}{|l|}{ Soil } & \multicolumn{3}{|c|}{ Soil+Green Compost } \\
\hline & & $\mathrm{DT}_{50}$ (days) & $\chi^{2}$ & $\mathrm{R}^{2}$ & $\mathrm{DT}_{50}$ (days) & $\chi^{2}$ & $\mathrm{R}^{2}$ \\
\hline \multirow[t]{7}{*}{ Trisulfuron $\left(\right.$ Logran $\left.{ }^{\circledR}\right)$} & $\mathrm{A}$ & $21.4^{\mathrm{a}}$ & 10.3 & 0.97 & $52.6^{\mathrm{a}}$ & 12.5 & 0.90 \\
\hline & & $20.7^{\mathrm{b}}$ & 8.6 & 0.98 & $52.6^{\mathrm{b}}$ & 13.3 & 0.90 \\
\hline & B & $22.8^{\mathrm{a}}$ & 17.2 & 0.96 & $33.3^{\mathrm{a}}$ & 15.1 & 0.88 \\
\hline & & $16.9^{\mathrm{b}}$ & 9.1 & 0.97 & $33.2^{\mathrm{b}}$ & 19.3 & 0.87 \\
\hline & $\mathrm{C}$ & $20.6^{\mathrm{a}}$ & 14.9 & 0.98 & $54.1^{\mathrm{a}}$ & 8.2 & 0.95 \\
\hline & & $20.6^{\mathrm{b}}$ & 20.1 & 0.98 & $54.1^{\mathrm{b}}$ & 8.8 & 0.95 \\
\hline & Mean \pm SD & $19.6 \pm 2.17$ & & & $46.7 * \pm 11.6$ & & \\
\hline \multirow[t]{6}{*}{ Trisulfuron (Auros Plus $\left.{ }^{(}\right)$} & $\mathrm{A}$ & $25.7^{\mathrm{ac}}$ & 6.5 & 0.99 & $23.5^{\mathrm{a}}$ & 5.8 & 0.99 \\
\hline & & $25.7^{\mathrm{b}}$ & 7.4 & 0.99 & $23.5^{\mathrm{b}}$ & 6.1 & 0.99 \\
\hline & $\mathrm{B}$ & $19.4^{\mathrm{a}}$ & 7.9 & 0.99 & $26.2^{\mathrm{a}}$ & 5.2 & 0.99 \\
\hline & & $19.4^{\mathrm{b}}$ & 8.4 & 0.99 & $26.2^{\mathrm{b}}$ & 5.7 & 0.99 \\
\hline & $\mathrm{C}$ & $28.4^{\mathrm{a}}$ & 10.4 & 0.96 & $23.8^{\mathrm{a}}$ & 10.1 & 0.97 \\
\hline & & $28.3^{\mathrm{b}}$ & 11.1 & 0.96 & $23.7^{\mathrm{b}}$ & 11.2 & 0.97 \\
\hline LSD (95\%) 13.33 & Mean \pm SD & $24.5 \pm 4.62$ & & & $24.5 \pm 1.48$ & & \\
\hline \multirow[t]{7}{*}{ Prosulfocarb (Auros $\left.{ }^{(}\right)$) } & $\mathrm{A}$ & $11.3^{\mathrm{a}}$ & 14.0 & 0.98 & $18.1^{\mathrm{a}}$ & 5.1 & 0.99 \\
\hline & & $15.2^{\mathrm{b}}$ & 38.4 & 0.98 & $18.1^{\mathrm{b}}$ & 5.5 & 0.99 \\
\hline & $\mathrm{B}$ & $15.1^{\mathrm{a}}$ & 12.9 & 0.96 & $18.3^{\mathrm{a}}$ & 5.4 & 0.99 \\
\hline & & $15.3^{\mathrm{b}}$ & 23.2 & 0.96 & $16.7^{\mathrm{b}}$ & 4.8 & 0.99 \\
\hline & $\mathrm{C}$ & $17.3^{\mathrm{a}}$ & 14.5 & 0.92 & $10.9^{\mathrm{a}}$ & 14.7 & 0.97 \\
\hline & & $22.1^{\mathrm{b}}$ & 28.5 & 0.91 & $7.8^{\mathrm{b}}$ & 12.1 & 0.98 \\
\hline & Mean \pm SD & $14.6 \pm 3.06$ & & & $14.2 \pm 5.59$ & & \\
\hline \multirow[t]{6}{*}{ Prosulfocarb (Auros Plus ${ }^{\circledR}$ ) } & A & $24.9^{\mathrm{a}}$ & 8.2 & 0.98 & $13.2^{\mathrm{a}}$ & 9.2 & 0.98 \\
\hline & & $24.9^{\mathrm{b}}$ & 8.8 & 0.98 & $11.5^{\mathrm{b}}$ & 8.3 & 0.99 \\
\hline & B & $14.4^{\mathrm{a}}$ & 3.9 & 0.99 & $17.4^{\mathrm{a}}$ & 8.8 & 0.98 \\
\hline & & $14.4^{\mathrm{b}}$ & 4.2 & 0.99 & $17.4^{\mathrm{b}}$ & 9.4 & 0.98 \\
\hline & $\mathrm{C}$ & $16.3^{\mathrm{a}}$ & 14.4 & 0.91 & $12.8^{\mathrm{a}}$ & 10.4 & 0.98 \\
\hline & & $17.7^{\mathrm{b}}$ & 14.7 & 0.90 & $12.8^{\mathrm{b}}$ & 11.1 & 0.98 \\
\hline LSD (95\%) 8.496 & Mean \pm SD & $18.5 \pm 5.59$ & & & $13.9 \pm 3.10$ & & \\
\hline
\end{tabular}

${ }^{\mathrm{a}} \overline{\mathrm{DT}}_{50}$ calculated from single first-order model (SFO); ${ }^{b} \mathrm{DT}_{50}$ calculated from first order multicompartment model (FOMC); ${ }^{\mathrm{c}} \mathrm{DT}_{50}$ include a lag phase of 9 days, ${ }^{*} \mathrm{DT}_{50}$ values marked with an asterisk indicate significant differences $(\mathrm{p}<0.05)$. 


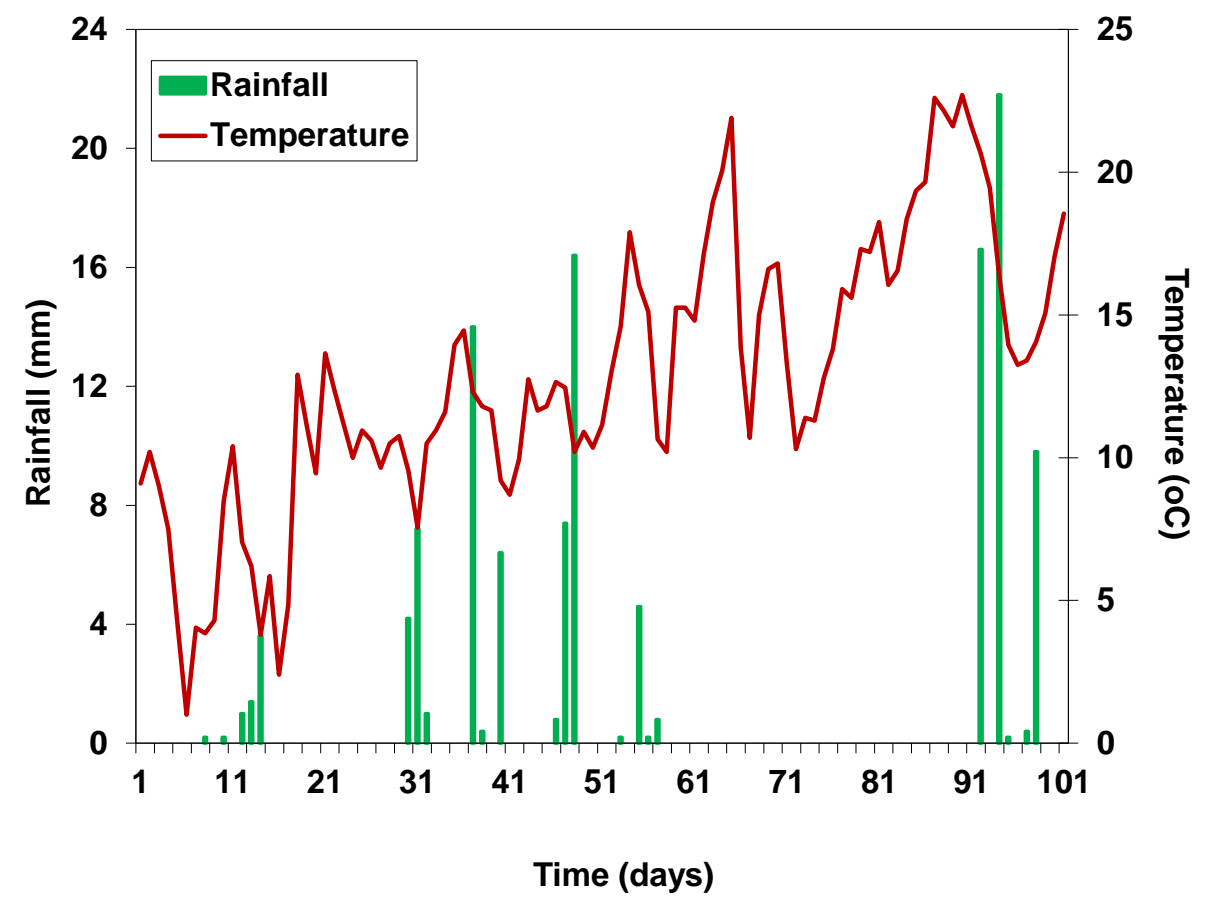

Figure 1 

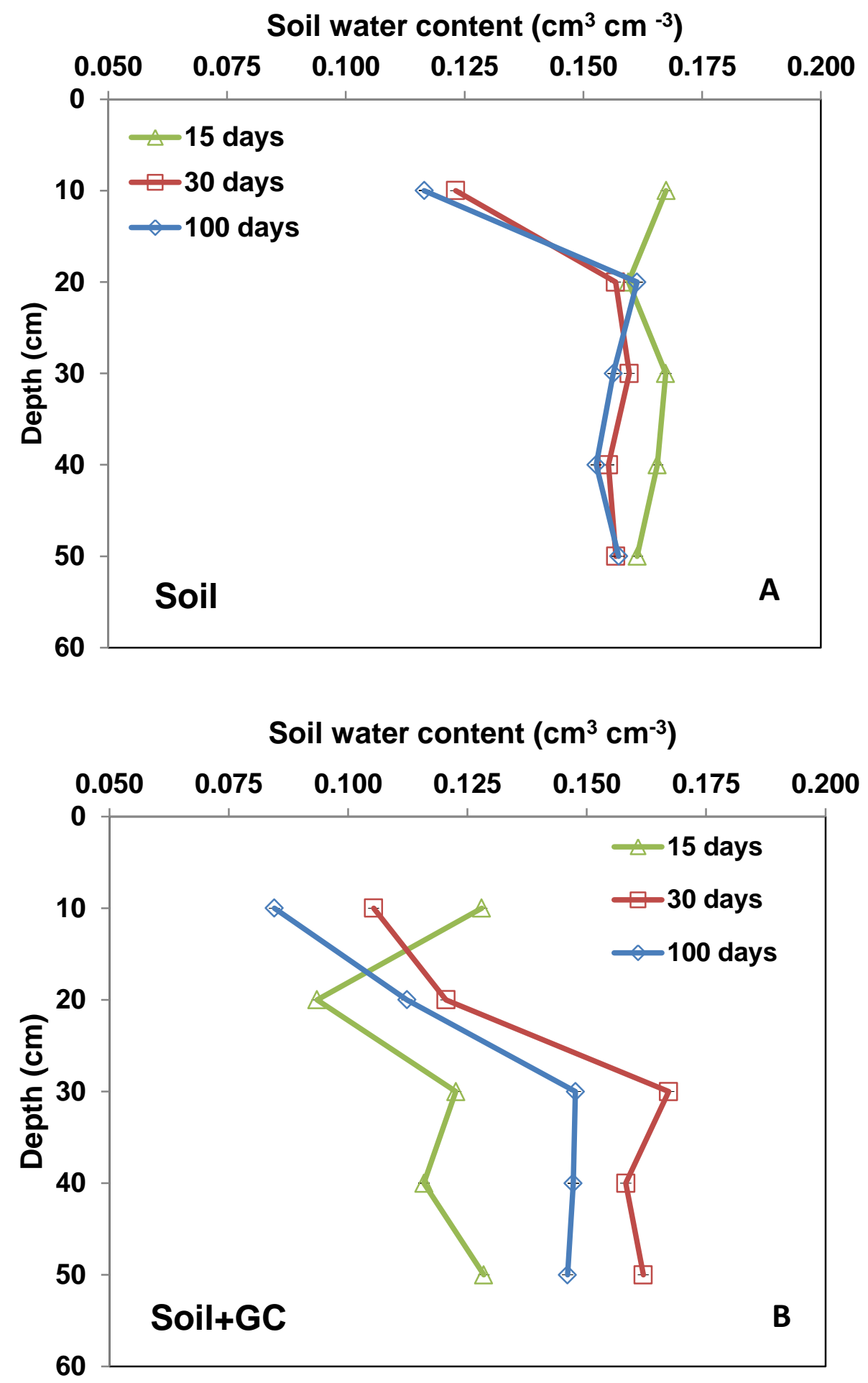

Figure 2 

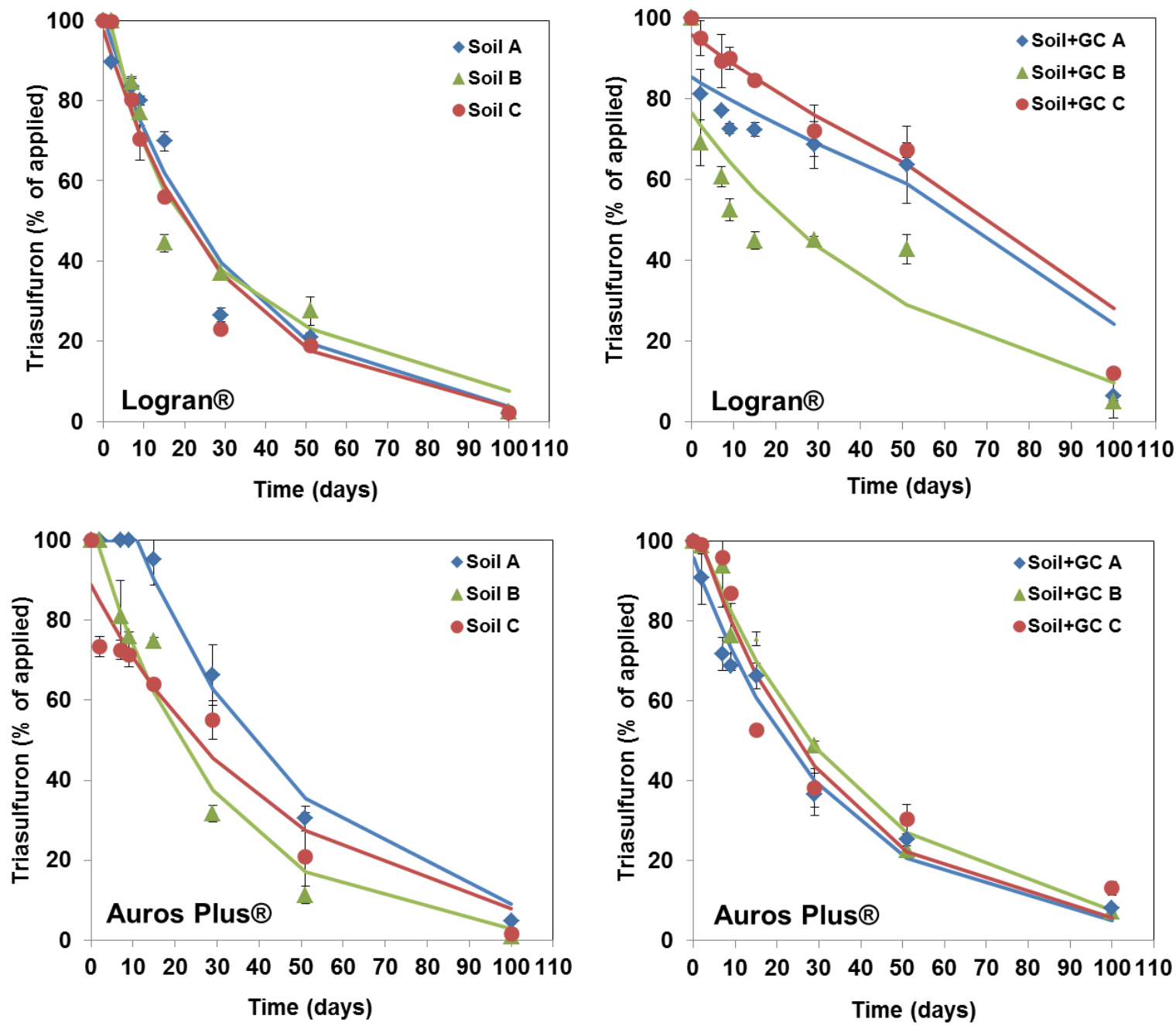

Figure 3 

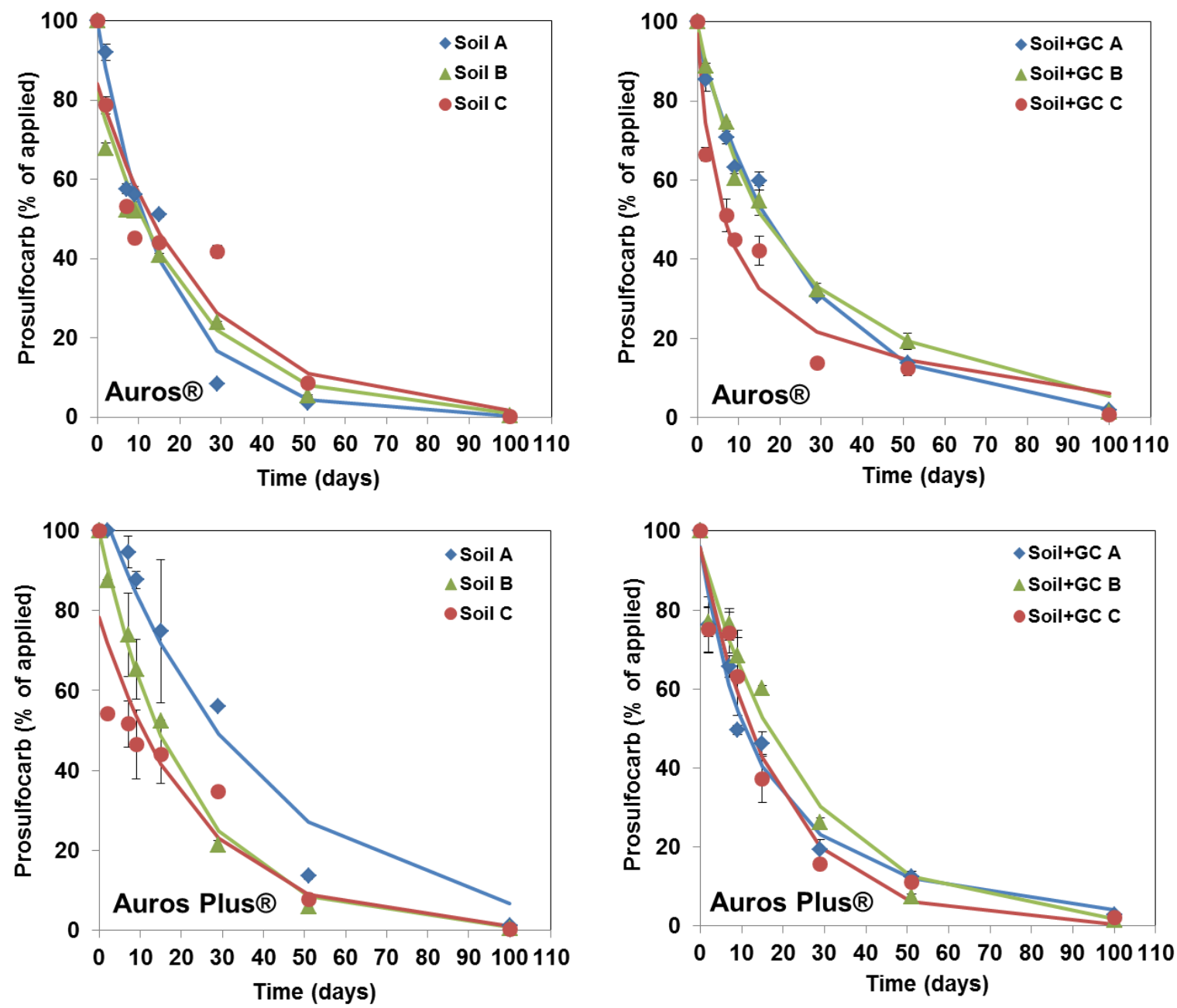

Figure 4 


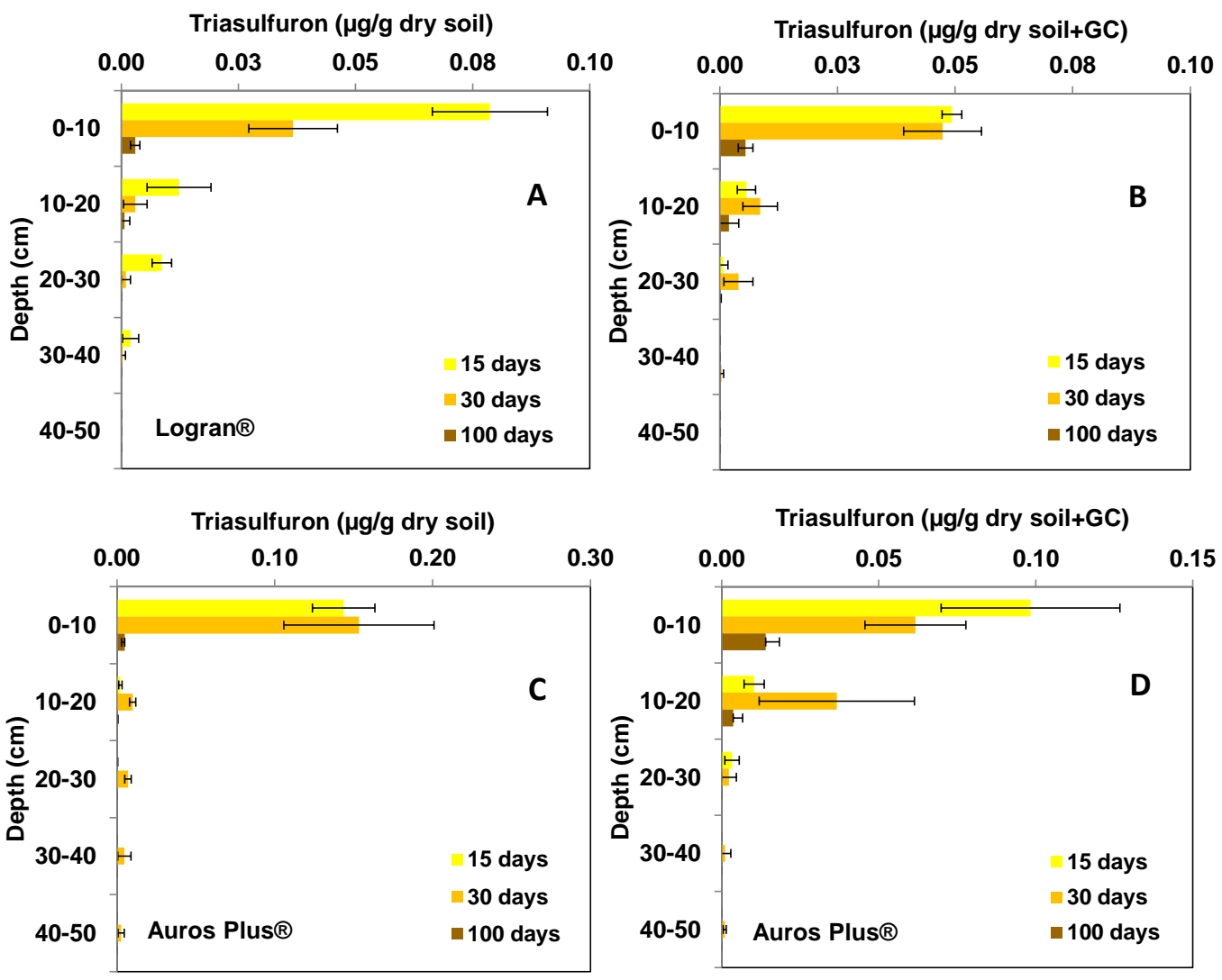

Figure 5 

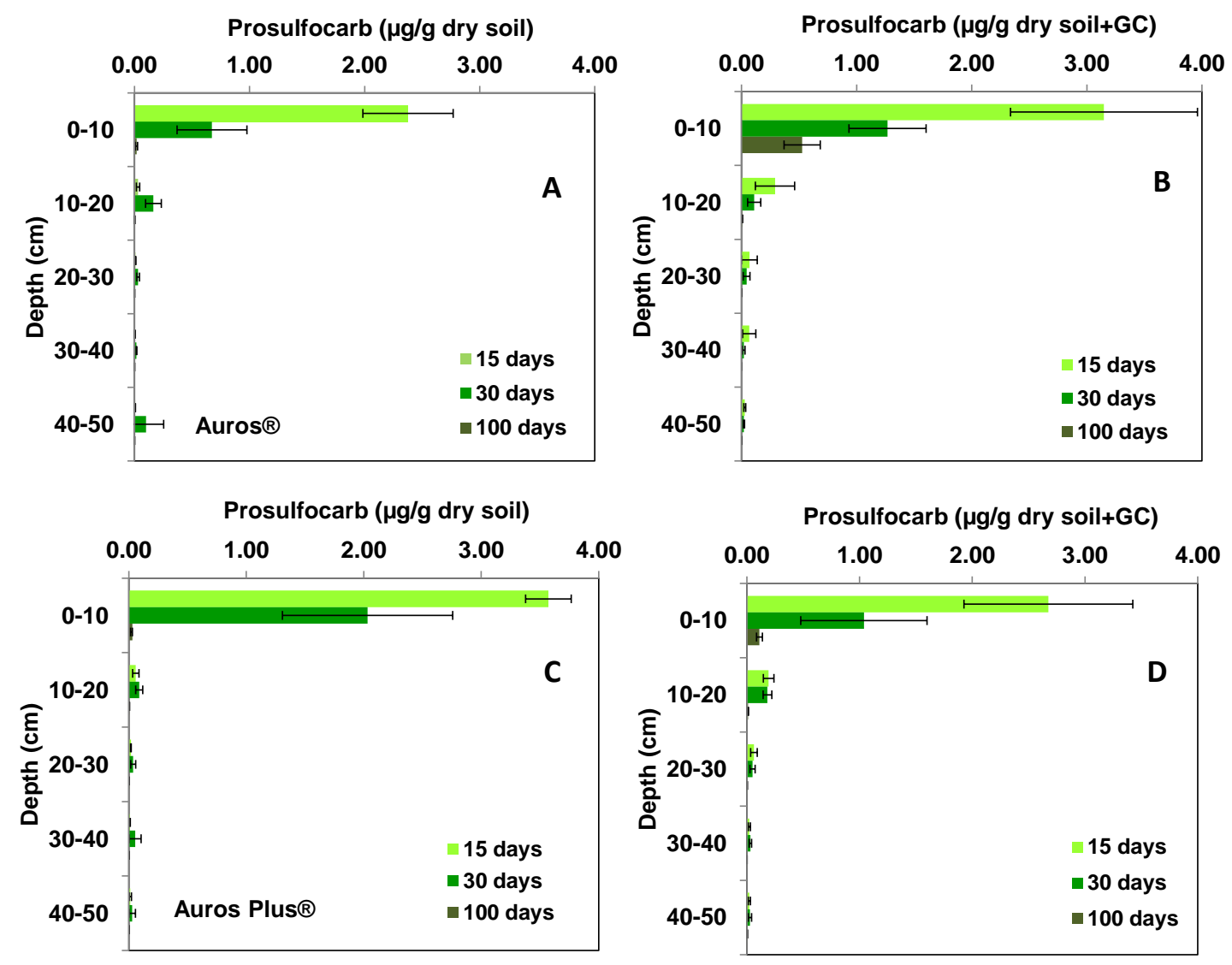

\section{Figure 6}




\section{Highlights}

- Field fate of triasulfuron and prosulfocarb was evaluated in an amended soil.

- Prosulfocarb dissipated faster than triasulfuron under all conditions assessed.

- Compost prevented rapid soil leaching of triasulfuron, but not for prosulfocarb.

- Influence of single or combined formulations was only observed for triasulfuron.

- Field data permit the design of rational joint application of compost and herbicides. 


\title{
SUPPLEMENTARY MATERIAL
}

\begin{abstract}
APPLICATION OF GREEN COMPOST AS AMENDMENT IN AN AGRICULTURAL SOIL: EFFECT ON THE BEHAVIOUR OF TRIASULFURON AND PROSULFOCARB UNDER FIELD CONDITIONS
\end{abstract}

J.M. Marín-Benito, V. Barba, J.M. Ordax, M.S. Andrades, M.J. Sánchez-Martín, M.S. Rodríguez-Cruz*

Instituto de Recursos Naturales y Agrobiología de Salamanca (IRNASA-CSIC), C/ Cordel de Merinas 40-52, 37008 Salamanca, España,

*Corresponding author.

E-mail address: msonia.rodriguez@irnasa.csic.es (María Sonia Rodríguez-Cruz)

Tel.: +34 923219606. Fax: +34 923219609

$N^{\circ}$ Pages: 5

$\mathrm{N}^{\mathrm{o}}$ Tables: 3

$\mathrm{N}^{\mathrm{o}}$ Figures: 1 


\section{Table S1}

Characteristics of herbicides (PPDB, 2017).

\begin{tabular}{|c|c|c|}
\hline & Triasulfuron & Prosulfocarb \\
\hline $\begin{array}{l}\text { Chemical name } \\
\text { (IUPAC) }\end{array}$ & $\begin{array}{l}\text { 1-[2-(2-chloroethoxy) } \\
\text { phenylsulfonyl]-3-(4-methoxy-6- } \\
\text { methyl-1,3,5-triazin-2-yl) urea }\end{array}$ & $\begin{array}{l}S \text {-benzyl } \\
\text { dipropyl(thiocarbamate) }\end{array}$ \\
\hline \multicolumn{3}{|l|}{$\begin{array}{l}\text { Chemical } \\
\text { structure }\end{array}$} \\
\hline $\begin{array}{l}\text { Water solubility } \\
\left(\mathrm{mg} \mathrm{L}^{-1}\right)\end{array}$ & $815\left(20^{\circ} \mathrm{C}, \mathrm{pH} 7\right)$ & $13.0\left(20^{\circ} \mathrm{C}, \mathrm{pH} 6.1\right)$ \\
\hline $\log$ Kow & $-0.59\left(20^{\circ} \mathrm{C}, \mathrm{pH} 7\right)$ & $4.48\left(20^{\circ} \mathrm{C}, \mathrm{pH} 7\right)$ \\
\hline $\begin{array}{l}\mathrm{DT}_{50} \text { (laboratory) } \\
\text { (days) }\end{array}$ & 59.1 & 12.4 \\
\hline $\begin{array}{l}\mathrm{DT}_{50}(\text { field }) \\
\text { (days) }\end{array}$ & 38.5 & 9.8 \\
\hline $\mathrm{pKa}$ & 4.64 (at $25^{\circ} \mathrm{C}$ ) & - \\
\hline GUS index ${ }^{a}$ & 5.12 & 0.84 \\
\hline
\end{tabular}

${ }^{\mathrm{a}}$ GUS index, Groundwater Ubiquity Score is an experimentally calculated value that relates pesticide half-life $\left(\mathrm{DT}_{50}\right)$ and Koc (from laboratory data) (GUS $=[\log$ $\mathrm{DT}_{50}$ ] [4 - $\left.\left.\log \mathrm{Koc}\right]\right)$. It is an indicator of the potential risk of water pollution, which allow classifying pesticides into potential leachers (GUS > 2.8), non-leachers (GUS < 1.8) and transient leachers (1.8 < GUS < 2.8) (Gustafson, D.I., 1989. Groundwater ubiquity score: a simple method for assessing pesticide leachability. Environ. Toxicol. Chem. 8, 339-357). 


\section{Table S2}

Validation parameters for determination of triasulfuron and prosulfocarb residues from unamended and green compost-amended soils by HPLC/MS analytical method.

\begin{tabular}{lccccc}
\hline $\begin{array}{l}\text { Pesticide/ } \\
\text { Soil sample }\end{array}$ & $\begin{array}{c}\text { Recovery } \\
\%\end{array}$ & $\begin{array}{c}\mathrm{RSD}^{\mathrm{a}} \\
\mathrm{n}=3\end{array}$ & $\mathrm{r}^{2 \mathrm{~b}}$ & $\begin{array}{c}\mathrm{LOD}^{\mathrm{c}} \\
\mu \mathrm{g} \mathrm{mL}^{-1}\end{array}$ & $\begin{array}{c}\mathrm{LOQ}^{\mathrm{c}} \\
\mu \mathrm{g} \mathrm{mL}^{-1}\end{array}$ \\
\hline Triasulfuron (Logran®) & & & & & \\
Soil & $83.2 \pm 3.21$ & 3.85 & 0.999 & 0.026 & 0.088 \\
Soil + GC & $80.4 \pm 4.71$ & 4.96 & 0.998 & 0.018 & 0.059
\end{tabular}

Triasulfuron

(AurosPlus ${ }^{\circledR}$ )

Soil

$82.9 \pm 2.24 \quad 3.26 \quad 0.999$

Soil + GC

$80.2 \pm 5.27$

6.15

0.999

Prosulfocarb (Auros®)

Soil

$\begin{array}{lllll}91.9 \pm 1.48 & 1.67 & 0.998 & 0.008 & 0.027\end{array}$

Soil + GC

$90.4 \pm 4.13 \quad 5.62$

0.999

0.005

0.017

Prosulfocarb

(AurosPlus ${ }^{\circledR}$ )

Soil

$81.9 \pm 3.62 \quad 4.18 \quad 0.998$

Soil + GC

$80.9 \pm 3.14$

3.91

0.997

${ }^{a}$ The accuracy and precision of the proposed method were determined by recovery experiments corresponding to soil samples spiked with $76.9 \mu \mathrm{g} \mathrm{kg}^{-1}$ for triasulfuron or $3.46 \mathrm{mg} \mathrm{kg}^{-1}$ for prosulfocarb and the relative standard deviations (RSD) of the signals or peak areas obtained for each herbicide. ${ }^{b}$ Lineal range $0.1-2.5 \mu \mathrm{g} \mathrm{mL}^{-1}$; a matrix-matched calibration in soil extracts was used to offset the matrix effect and avoid any under/over estimation of herbicides. ${ }^{c}$ LODs and LOQs were estimated as the analyte concentration with a signal-to-noise ratio of 3 and 10, respectively. 


\section{Table S3}

Adsorption coefficients $\left(\mathrm{K}_{\mathrm{d}}\right)$ of triasulfuron and prosulfocarb by unamended and green compost amended soil from experimental depths of soil profile.

\begin{tabular}{|c|c|c|c|c|c|}
\hline \multirow{2}{*}{$\begin{array}{l}\text { Adsorption coefficient } \\
\mathrm{K}_{\mathrm{d}}\end{array}$} & \multicolumn{5}{|c|}{ Soil depth $(\mathrm{cm})$} \\
\hline & $0-10$ & $10-20$ & $20-30$ & $30-40$ & $40-50$ \\
\hline \multirow[t]{2}{*}{ Triasulfuron $\left(\right.$ Logran $\left.{ }^{\circledR}\right)$} & $0.05 \pm 0.01^{\mathrm{a}}$ & $0.13 \pm 0.11$ & $0.23 \pm 0.06$ & $0.22 \pm 0.01$ & $0.18 \pm 0.03$ \\
\hline & $0.53 \pm 0.14^{b}$ & - & - & - & - \\
\hline \multirow[t]{2}{*}{ Triasulfuron (Auros Plus ${ }^{\circledR}$ ) } & $0.31 \pm 0.01^{\mathrm{a}}$ & $0.30 \pm 0.04$ & $0.28 \pm 0.04$ & $0.32 \pm 0.04$ & $0.29 \pm 0.01$ \\
\hline & $0.38 \pm 0.09^{b}$ & - & - & - & - \\
\hline \multirow[t]{2}{*}{ Prosulfocarb (Auros ${ }^{\circledR}$ ) } & $24.1 \pm 4.28^{\mathrm{a}}$ & $18.6 \pm 4.53$ & $11.6 \pm 0.22$ & $7.40 \pm 0.66$ & $3.13 \pm 0.77$ \\
\hline & $37.2 \pm 5.69^{\mathrm{b}}$ & - & - & - & - \\
\hline \multirow[t]{2}{*}{ Prosulfocarb (Auros Plus ${ }^{\circledR}$ ) } & $21.6 \pm 5.55^{\mathrm{a}}$ & $13.3 \pm 0.27$ & $9.56 \pm 0.59$ & $6.23 \pm 0.28$ & $2.73 \pm 0.39$ \\
\hline & $30.7 \pm 7.62^{b}$ & - & - & - & - \\
\hline
\end{tabular}

${ }^{\mathrm{a}}$ Unamended soil, ${ }^{\mathrm{b}}$ Green compost amended soil 
* 8 treatments (3 replicates A-B-C)

* 24 experimental plots $\left(3 \times 3 \mathrm{~m}^{2}\right)$

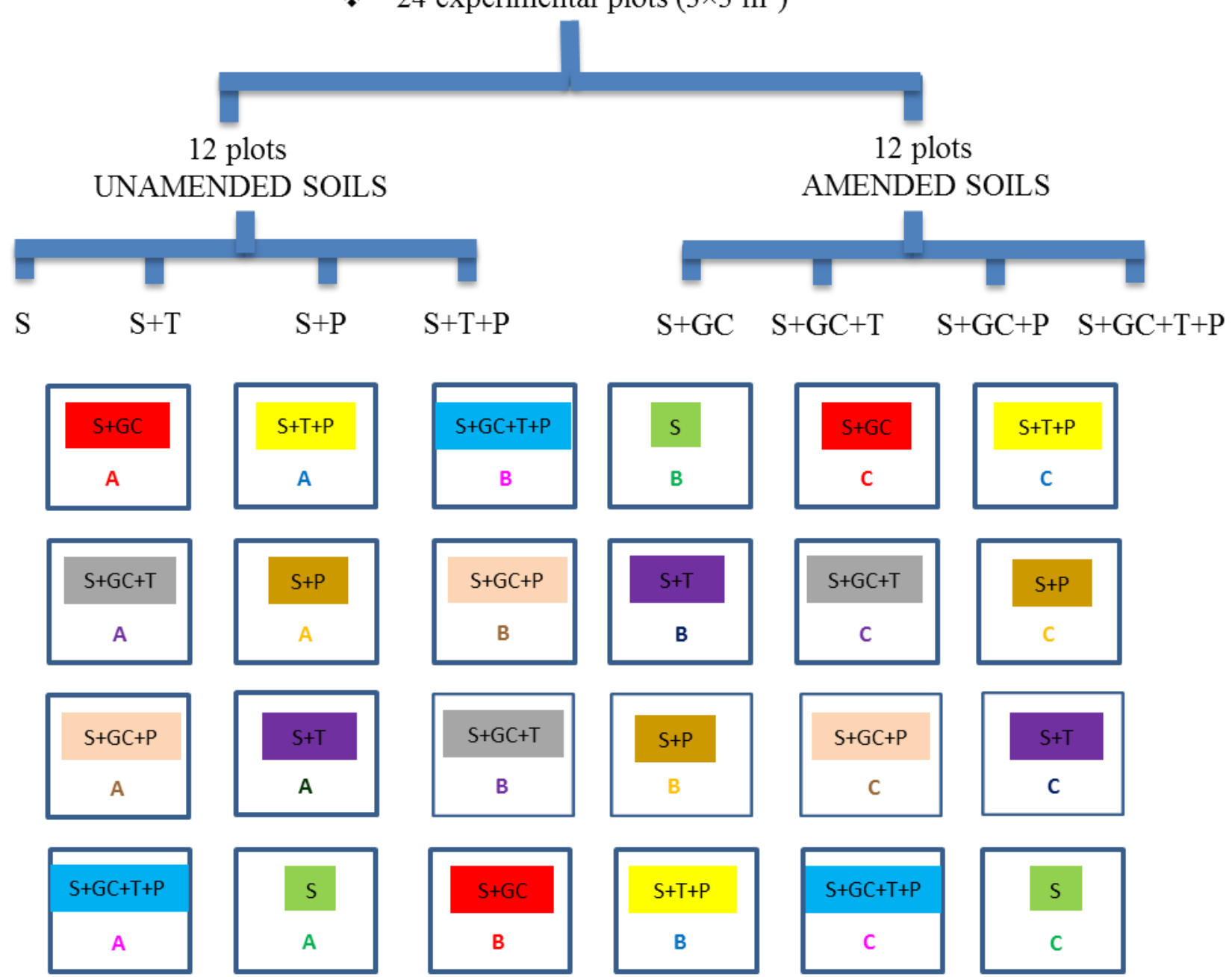

$\mathrm{S}=$ soil, $\mathrm{S}+\mathrm{GC}=$ soil + green compost, $\mathrm{T}=$ triasulfuron, $\mathrm{P}=$ prosulfocarb

\section{Figure S1}

Experimental set-up 